\title{
Detailed Kinetic Mechanism for the Oxidation of Ammonia Including the Formation and Reduction of Nitrogen Oxides
}

\author{
Krishna P. Shrestha ${ }^{1}$, Lars Seidel ${ }^{3,}$, Thomas Zeuch ${ }^{2}$ and Fabian Mauss ${ }^{1}$ \\ 1 Thermodynamics and Thermal Process Engineering, Brandenburg University of Technology, \\ Siemens-Halske-Ring 8, 03046 Cottbus, Germany \\ 2 Institut für Physikalische Chemie, Georg-August-Universität Göttingen, Tammannstraße 6, \\ 37077 Göttingen, Germany \\ 3 LOGE Deutschland GmbH, Burger Chaussee 25, 03044 Cottbus, Germany
}

Published in Energy Fuels 2018, 32, 10, 10202-10217

https://doi.org/10.1021/acs.energyfuels.8b01056 


\begin{abstract}
This work introduces a newly developed reaction mechanism for the oxidation of ammonia in freely propagating and burner stabilized premixed flames as well as in shock tubes, jet stirred reactors and plug flow reactors experiments. The paper mainly focuses on pure ammonia and ammonia-hydrogen fuel blends. The reaction mechanism also considers the formation of nitrogen oxides, as well as the reduction of nitrogen oxides depending on the conditions of the surrounding gas phase. Doping of the fuel blend with $\mathrm{NO}_{2}$ can result in acceleration of $\mathrm{H}_{2}$ autoignition via the reaction $\mathrm{NO}_{2}+\mathrm{HO}_{2} \leftrightharpoons \mathrm{HONO}+\mathrm{O}_{2}$ followed by the thermal decomposition of $\mathrm{HONO}$, or in deceleration of $\mathrm{H}_{2}$ oxidation via $\mathrm{NO}_{2}+\mathrm{OH} \leftrightharpoons \mathrm{NO}+\mathrm{HO}_{2}$. The concentration of $\mathrm{HO}_{2}$ is decisive for the active reaction pathway. The formation of NO in burner stabilized premixed flames is shown to demonstrate the capability of the mechanism to be integrated into a mechanism for hydrocarbon oxidation.
\end{abstract}




\section{Introduction}

Clean, reliable and renewable fuels are important for future power systems. Alternative fuels for power generation and internal combustion engines of various transportation systems have recently been intensely discussed. Hydrogen has attracted attention as a carbon free transportation fuel with zero- $\mathrm{CO}_{2}$ emissions. It can be produced in an electrolytic process from overpower of alternative energy sources, i.e. wind or solar power. Its low energy density and its limited storage capabilities are still barriers for a market launch of hydrogen fueled vehicles. Alternatively, Hydrogen is discussed as a reactant for catalytic carbonization processes leading from $\mathrm{CO}_{2}$ to methane or methanol.

For any hydrogen-atom containing fuel the hydrogen-oxygen chemistry plays a fundamental role. Hydrogen is not only an important fuel, but the chemical kinetics involving $\mathrm{H}, \mathrm{O}, \mathrm{OH}, \mathrm{HO}_{2}, \mathrm{H}_{2} \mathrm{O}$ and $\mathrm{H}_{2} \mathrm{O}_{2}$ also determine the radical pool in hydrocarbon reaction systems ${ }^{1}$. Reactions from this sub-mechanism show the highest sensitivity in almost all hydrocarbon oxidation systems.

Investigations of alternative fuels aim at decreasing the usage of fossil fuels at reasonable transportation costs. Ammonia was considered until the 1960s and recently gained attention again. It is also known as one key species in the de-NOx process ${ }^{2-5}$, which can be applied in a narrow temperature window within the combustion chamber or in a catalytic aftertreatment system. Ammonia is recognized as a carbon free fuel and as a hydrogen carrier or storage compound ${ }^{6,7}$ with a high content of hydrogen atoms per unit volume. Ammonia is catalytically produced from nitrogen and hydrogen. Although the industrial process technology has been steadily improved over the years, it still compares to the process developed by Haber and Bosch in the early 20th century: $\mathrm{N}_{2}(\mathrm{~g})+3 \mathrm{H}_{2}(\mathrm{~g}) \rightarrow 2 \mathrm{NH}_{3}(\mathrm{~g})\left(\Delta \mathrm{H}^{0}{ }_{298}=-92.2 \mathrm{~kJ} /\right.$ mole $)$. As hydrogen still must be produced to obtain ammonia in large quantities, ammonia can be seen as an additional hydrogen energy 
vector. The industrial ammonia production process is highly optimized and hard to improve and it is unclear as to whether catalytic carbonization processes can become significantly more efficient in future.

Ammonia is carbon-free and can potentially be burned in an environmentally benign way, exhausting water, nitrogen and nitrogen oxides as only emissions. However, the combustion of ammonia as a fuel in internal combustion engines also has several drawbacks ${ }^{8}$; i.e. low laminar flame speed, high auto-ignition temperature, high heat of vaporization, narrow flammability limits (16-25\% by volume in air) and high toxicity. It is therefore considered as a dual fuel component. This was demonstrated in modified spark-ignition (SI) and compression-ignition (CI) engines at research ${ }^{9,10}$ or prototype level ${ }^{11}$. Depending on the combustion process ammonia can either lead to reduced or increased $\mathrm{NO}_{\mathrm{x}}$ emissions.

To support the engine development process by simulations, detailed mechanisms for the oxidation of ammonia including the formation and the reduction of $\mathrm{NO}_{\mathrm{x}}$ are needed. Previous studies ${ }^{12-17}$ have reported on the development of detailed chemical mechanisms for the $\mathrm{NH}_{3} / \mathrm{NO}_{\mathrm{x}}$ system. However the parameter ranges for the validation of these mechanisms was limited due to the lack of experimental data. For example, Mathieu et al. ${ }^{17}$ compared the predictions of nine different mechanisms from the literature against their measured data from shock tube experiments and concluded that further model improvements are needed for spanning the experimentally explored range of conditions. Other authors came to similar conclusions: Hayakawa et al. ${ }^{18}$, for the prediction of laminar flame speeds of ammonia/air blends in a constant volume cylindrical combustion chamber under elevated pressure conditions; Xiao et al. ${ }^{19}$ for the prediction of $\mathrm{NH}_{3} / \mathrm{H}_{2}$ laminar flame speeds from $\mathrm{Li}$ et al. ${ }^{20}$ and $\mathrm{NH}_{3}$ ignition delay times from shock tube experiments ${ }^{17}$. Recently, Zhang et al. ${ }^{21}$ developed a detailed kinetic mechanism for the $\mathrm{H}_{2} / \mathrm{NO}_{\mathrm{x}}$ and 
Syngas/NOx systems. They demonstrated the sensitivity of the thermochemistry on the prediction of shock tube ignition delay times, species concentrations in a jet stirred reactor (JSR) and a flow reactor (FR). However, their study does not include $\mathrm{NH}_{3}$ containing fuel blends.

This situation calls for the development of a detailed kinetic $\mathrm{H}_{2} / \mathrm{CO} / \mathrm{C}_{1} / \mathrm{NH}_{3} / \mathrm{NO}_{\mathrm{x}}$ model with a significantly extended validation target range, which is the objective of the present work. To this end the here derived model is critically tested taking into account laminar flame speeds, ignition delay times, speciation in jet stirred reactors (JSR), in plug flow reactors (PFR) and in burner stabilized flames (BSF). The compilation strategy for our new "nested" mechanism is along the lines we have established for $\mathrm{C} 1-\mathrm{C} 8$ hydrocarbon fuels in the past fifteen years (e.g. ${ }^{22-27}$ ). The idea is to merge existing, well tested models and adapt the resulting mechanism to simulations comprising a much broader target range than all previous studies. For the identified elementary reaction steps with highly sensitive kinetic data the increased simulation constraints by the augmented target range allow for a more consistent choice of kinetic parameters within the plausible margins. The virtues of our nested mechanism approach were very recently discussed by Westbrook and co-workers in a review type paper on the development and improvement of kinetic models from the beginnings in the 1970ies to present applications in engine simulations ${ }^{28}$.

In this paper we concentrate on the $\mathrm{H}_{2} / \mathrm{NH}_{3} / \mathrm{NO}_{\mathrm{x}}$ model, and limit the demonstration of the $\mathrm{C}_{1}$ system to one illustrative experiment by Lamoureux et al. ${ }^{16}$. A wider range of experiments is shown in the supporting information, together with the detailed reaction mechanisms used in this work. 


\section{Development of the kinetic model}

The development of the model is discussed here in three subsections. To keep the paper easy to read we focus on the new aspects of the here derived model and refer to the literature where similar compilations for sub-mechanisms exist. In the first subsection the $\mathrm{H}_{2} / \mathrm{CO}$ sub-model is only briefly described. Here the kinetic data is mainly taken from existing databases. The subsection on the $\mathrm{NH}_{3} / \mathrm{NO}_{\mathrm{x}}$ sub-model introduces a newly merged model and explains the choice of kinetic data from the available references. Here the kinetic data for several highly sensitive reactions were discussed in more detail. The $\mathrm{C}_{1} / \mathrm{NO}_{\mathrm{x}}$ mechanisms is literature based and selectively augmented for $\mathrm{H}_{2} / \mathrm{NO}_{\mathrm{x}} / \mathrm{C}_{1}$ cross reactions.

$\underline{\mathbf{2 . 1} \mathrm{H}_{2} / \mathrm{CO} \text { kinetic model: }}$ The detailed chemical kinetic mechanism of $\mathrm{H}_{2}$ and $\mathrm{CO}$ is mostly based on the recommendations of Baulch et al. ${ }^{29}$ and the uncertainty boundaries proposed by the authors. We refer Baulch et al. ${ }^{29}$ because it is a comprehensive source, which provides a detailed discussion of uncertainties for the compiled reaction rate constants. Elementary reactions which were not available from ${ }^{29}$, or which cannot be expressed in the standard Chemkin format are adopted from other publications ${ }^{30-33}$. The $\mathrm{H}_{2} / \mathrm{CO}$ kinetic model is validated against experimental data from literature which include 87 sets of laminar flame speed, 39 sets of ignition delay times from shock tubes, 16 sets species concentrations in JSRs, 27 sets of species concentrations in PFRs, 8 sets of species concentrations in BSF and 4 sets of species concentrations in shock tube experiments. The choice of kinetic data in the resulting mechanism and its performance is similar to other publications of this decade ${ }^{33-43}$. The detailed mechanism for the $\mathrm{H}_{2} / \mathrm{CO}$ model is provided in supporting information of this work. The full set of validation calculations is found on ${ }^{44}$.

$\underline{2.2} \mathrm{NH}_{3} / \mathbf{N O}_{\mathrm{x}}$ kinetic model: The starting point of the NO formation and reduction mechanism was the development by Lamoureux et al. ${ }^{16}$. Though they validated their model against own data 
and a large set of experimental data from literature, they did not consider experiments dedicated to ammonia in their model development. We therefore do not demonstrate any extensive comparison of predictions of the model used in this work and the original model from ${ }^{16}$. However to underline why the model update is necessary we will show an ammonia-air laminar flame speed comparison between Lamoureux et al. ${ }^{16}$ and the present work. To match the large set of experimental data published in the literature the complete $\mathrm{NO}_{\mathrm{x}}$ sub mechanism needed to be revised and updated very carefully.

Moreover we included additional nine nitrogen containing species $-\mathrm{N}_{2} \mathrm{H}_{3}, \mathrm{~N}_{2} \mathrm{H}_{4}, \mathrm{H}_{2} \mathrm{NN}, \mathrm{HNOH}$, $\mathrm{NH}_{2} \mathrm{OH}, \mathrm{HNO}_{2}, \mathrm{HONO}_{2}, \mathrm{NO}_{3}$ and $\mathrm{HNO}_{3}$ - and their respective sub-mechanisms. The importance of the inclusion of the $\mathrm{N}_{2} \mathrm{H}_{x}$ chemistry in $\mathrm{NO}_{x}$ modelling is shown by Allen et al. ${ }^{45}$ in their experimental and numerical work on the oxidation of $\mathrm{H}_{2} / \mathrm{N}_{2} \mathrm{O}$ mixtures in a flow reactor. The inclusion of these sub-mechanisms has made updates in the original mechanism necessary. Most of the published models in literature are dedicated to particular fuels or mixtures of interest for a limited range of conditions. The novelty of the present model comes from the ability to comprehensively address the pure fuels $\left(\mathrm{H}_{2}, \mathrm{H}_{2} / \mathrm{CO}, \mathrm{NH}_{3}, \mathrm{CH}_{4}, \mathrm{CH}_{3} \mathrm{OH}, \mathrm{CH}_{2} \mathrm{O}\right)$ and mixtures at the same time for a large set of experimental conditions. Sub-mechanism of $\mathrm{NH}_{3}, \mathrm{NH}, \mathrm{NH}_{2}, \mathrm{~N}_{2} \mathrm{H}_{2}$, $\mathrm{NO}, \mathrm{NO}_{2}, \mathrm{~N}_{2} \mathrm{O}$ etc. which were already present in initial mechanism from ${ }^{16}$ were also updated. The reactions presented in Table 1 have been identified as highly important for the here presented model and its performance. 
Table 1: List of important reaction identified in $\mathrm{H} / \mathrm{N} / \mathrm{O}$ scheme. Units are cm, mol, s, cal

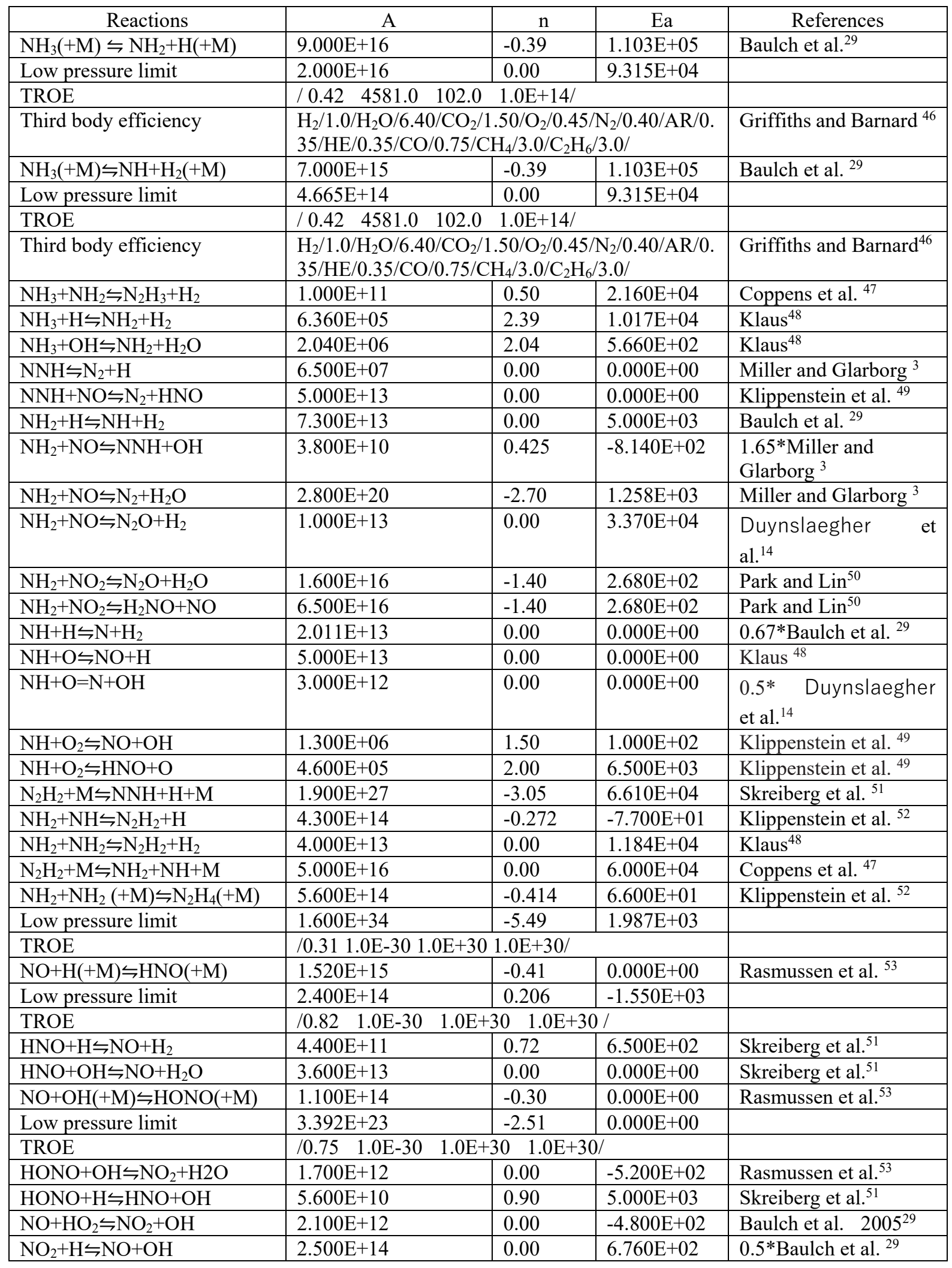




\begin{tabular}{|c|c|c|c|c|}
\hline $\mathrm{NO}+\mathrm{O}(+\mathrm{M}) \leftrightharpoons \mathrm{NO}_{2}(+\mathrm{M})$ & $2.950 \mathrm{E}+14$ & -0.40 & $0.000 \mathrm{E}+00$ & Baulch et al. $2005^{29}$ \\
\hline Low pressure limit & $3.336 \mathrm{E}+20$ & -1.60 & $0.000 \mathrm{E}+00$ & \\
\hline TROE & \multicolumn{3}{|c|}{$/ 0.80 \quad 1.0 \mathrm{E}-30 \quad 1.0 \mathrm{E}+30 \quad 1.0 \mathrm{E}+30 /$} & \\
\hline Third body efficiency & \multicolumn{3}{|c|}{$\begin{array}{l}\mathrm{H}_{2} / 1.0 / \mathrm{H}_{2} \mathrm{O} / 6.40 / \mathrm{CO}_{2} / 1.50 / \mathrm{O}_{2} / 0.45 / \mathrm{N}_{2} / 0.40 / \mathrm{AR} / 0 . \\
35 / \mathrm{HE} / 0.35 / \mathrm{CO} / 0.75 / \mathrm{CH}_{4} / 3.0 / \mathrm{C}_{2} \mathrm{H}_{6} / 3.0 /\end{array}$} & Griffiths and Barnard ${ }^{46}$ \\
\hline $\mathrm{NO}_{2}+\mathrm{HO}_{2} \leftrightharpoons \mathrm{HONO}+\mathrm{O}_{2}$ & $1.910 \mathrm{E}+00$ & 3.32 & $3.044 \mathrm{E}+03$ & Rasmussen et al. ${ }^{53}$ \\
\hline $\mathrm{NO}_{2}+\mathrm{H}_{2} \leftrightharpoons \mathrm{HONO}+\mathrm{H}$ & $1.300 \mathrm{E}+04$ & 2.76 & $2.977 \mathrm{E}+04$ & Rasmussen et al..$^{53}$ \\
\hline $\mathrm{N}_{2} \mathrm{O}(+\mathrm{M}) \leftrightharpoons \mathrm{N}_{2}+\mathrm{O}(+\mathrm{M})$ & $1.300 \mathrm{E}+12$ & 0.00 & $6.257 \mathrm{E}+04$ & Röhrig et al. ${ }^{54}$ \\
\hline Low pressure limit & $4.00 \mathrm{E}+14$ & 0.00 & $5.660 \mathrm{E}+04$ & \\
\hline Third body efficiency & \multicolumn{3}{|c|}{$\mathrm{N}_{2} / 1.7 / \mathrm{O}_{2} / 1.4 / \mathrm{CO}_{2} / 3.0 / \mathrm{H}_{2} \mathrm{O} / 12.0 /$} & \\
\hline $\mathrm{N}_{2} \mathrm{O}+\mathrm{H} \leftrightharpoons \mathrm{N}_{2}+\mathrm{OH}$ & $2.530 \mathrm{E}+10$ & 0.00 & $4.550 \mathrm{E}+03$ & Powell et al. ${ }^{55}$ \\
\hline \multicolumn{5}{|l|}{ DUPLICATE } \\
\hline $\mathrm{N}_{2} \mathrm{O}+\mathrm{H} \leftrightharpoons \mathrm{N}_{2}+\mathrm{OH}$ & $5.000 \mathrm{E}+14$ & 0.00 & $1.810 \mathrm{E}+04$ & \\
\hline \multicolumn{5}{|l|}{ DUPLICATE } \\
\hline $\mathrm{N}_{2} \mathrm{O}+\mathrm{H} \leftrightharpoons \mathrm{N}_{2}+\mathrm{OH}^{*}$ & $1.600 \mathrm{E}+14$ & 0.00 & $5.030 \mathrm{E}+04$ & Hidaka et al. ${ }^{56}$ \\
\hline $\mathrm{NO}_{2}+\mathrm{HO}_{2} \leftrightharpoons \mathrm{HONO}+\mathrm{O}_{2}$ & $1.910 \mathrm{E}+00$ & 3.32 & $3.044 \mathrm{E}+03$ & Rasmussen et al..$^{53}$ \\
\hline $\mathrm{NO}_{2}+\mathrm{HO}_{2} \leftrightharpoons \mathrm{HNO}_{2}+\mathrm{O}_{2}$ & $1.850 \mathrm{E}+01$ & 3.26 & $4.983 \mathrm{E}+03$ & Rasmussen et al. ${ }^{53}$ \\
\hline $\mathrm{HNO}_{2}(+\mathrm{M}) \leftrightharpoons \mathrm{HONO}(+\mathrm{M})$ & $2.500 \mathrm{E}+14$ & 0.00 & $3.230 \mathrm{E}+04$ & Rasmussen et al..$^{53}$ \\
\hline Low pressure limit & $3.100 \mathrm{E}+18$ & 0.00 & $3.150 \mathrm{E}+04$ & \\
\hline TROE & \multicolumn{3}{|c|}{$\begin{array}{llll}1.149 & 1 \mathrm{E}-30 & 3.125 \mathrm{E}+03 & 1 \mathrm{E}+30 /\end{array}$} & \\
\hline
\end{tabular}

The thermal $\mathrm{NO}_{\mathrm{x}}$ formation is given by the Zeldovich mechanism ${ }^{57}$. The rate parameters of these reactions are adopted from the recommendation of Baulch et al. ${ }^{29}$ and optimized within the uncertainty limits provided by the authors to best match experimental data from the literature. A detailed description of other sub-mechanisms which are included in the $\mathrm{NH}_{3} / \mathrm{NO}_{\mathrm{x}}$ scheme and the adaptation of the rate parameters are briefly explained below highlighting the important reactions and their kinetics. We follow the kinetic models from Skreiberg et al. ${ }^{51}$, Klippenstein et al. ${ }^{49,52}$, Miller and Glarborg ${ }^{3}$, Glarborg et al. ${ }^{58,59}$, Klaus $^{48}$, Allen et al. ${ }^{12}$, Coppens et al. ${ }^{47}$, Mathieu et al. ${ }^{17}$, Mendiara and Glarborg ${ }^{60}$, Powell et al. ${ }^{55}$, Duynslaegher et al. ${ }^{14}$ and Rasmussen et al. ${ }^{53}$ and sources cited therein.

\section{$\mathrm{NO}_{2}$ sub-mechanism:}


$\mathrm{NO}_{2}$ kinetics is one of the most important sub-mechanisms in almost all of the cases studied here, which are ignition delay times in shock tube experiments, speciation in flow reactors and jet stirred reactor studies on the $\mathrm{H}_{2} / \mathrm{O}_{2} / \mathrm{NO}_{\mathrm{x}}$ and $\mathrm{C}_{1} / \mathrm{NO}_{\mathrm{x}}$ systems. The reactions are very important and highly sensitive in the interconversion process of $\mathrm{NO} \leftrightarrow \mathrm{NO}_{2}$ which is discussed in the results and discussion part of this paper (speciation in JSR and PFR). Reactions involving $\mathrm{NO}_{2}$ are also sensitive on ignition delay time predictions, which is apparent from the sensitivity analysis in Figure 4. Reactions particularly important in the formation/consumption of $\mathrm{NO}_{2}$ are:

$\mathrm{NO}+\mathrm{HO}_{2} \rightleftharpoons \mathrm{NO}_{2}+\mathrm{OH}$

$\mathrm{NO}_{2}+\mathrm{H} \rightleftharpoons \mathrm{NO}+\mathrm{OH}$.

In this study, rate parameters for these two reactions are adopted from Baulch et al. ${ }^{29}$. The importance of these two reactions in promoting the reactivity of the system by forming $\mathrm{OH}$ radicals has been discussed in many studies ${ }^{53,61-64}$. In this work the rate constant of the $\mathrm{NO}_{2}+\mathrm{H} \rightleftharpoons \mathrm{NO}+\mathrm{OH}$ reaction has been decreased by $50 \%$ to best match the wide range of experimental data taken into consideration which is within the uncertainty proposed by Baulch et al. ${ }^{29}$.

For lean and high pressure conditions $\mathrm{NO}_{2}$ can also be formed via the reaction $\mathrm{NO}+\mathrm{O}(+\mathrm{M})$ $\rightleftharpoons \mathrm{NO}_{2}(+\mathrm{M})$; the rate parameters of this reaction are taken from the recommendation of Baulch et al. ${ }^{29}$ in the temperature range of $200-2000 \mathrm{~K}$. The rate constant of the reaction $\mathrm{NO}_{2}+\mathrm{O} \rightleftharpoons \mathrm{NO}+\mathrm{O}_{2}$ is adopted from experimental work of Bemand et al.$^{65}$ who performed direct measurements in the temperature range of $298-1055 \mathrm{~K}$. The suggested rate is consistent with the experimental studies by Estupiñán et al. ${ }^{66}$, Avallone ${ }^{67}$ and the theoretical study of Shiekh et al. ${ }^{68}$. Another reaction, which is important under typical combustion conditions, is $\mathrm{NO}_{2}+\mathrm{HO}_{2} \rightleftharpoons \mathrm{HONO} / \mathrm{HNO}_{2}+\mathrm{O}_{2}$. Glarborg et al. ${ }^{69}$ in their formaldehyde-NOx interaction study pointed out that the reaction 
$\mathrm{NO}_{2}+\mathrm{HO}_{2} \rightleftharpoons \mathrm{HONO}+\mathrm{O}_{2}$ competes for the $\mathrm{HO}_{2}$ radical with the reaction $\mathrm{HO}_{2}+\mathrm{OH} \rightleftharpoons \mathrm{H}_{2} \mathrm{O}+\mathrm{O}_{2}$. Also in the shock tube study of Mathieu et al. ${ }^{63}$ on the $\mathrm{H}_{2} / \mathrm{O}_{2} / \mathrm{NO}_{2} / \mathrm{Ar}$ system $\mathrm{NO}_{2}+\mathrm{HO}_{2} \rightleftharpoons \mathrm{HONO}+\mathrm{O}_{2}$ is significant in the sensitivity analysis when $100 \mathrm{ppm}$ and $400 \mathrm{ppm}$ of $\mathrm{NO}_{2}$ are present in the initial mixture. Rasmussen et al. ${ }^{53}$ performed a theoretical study on $\left(\mathrm{NO}_{2}+\mathrm{HO}_{2} \rightleftharpoons \mathrm{HONO}+\mathrm{O} 2\right.$, $\left.\mathrm{NO}_{2}+\mathrm{HO}_{2} \rightleftharpoons \mathrm{HNO}_{2}+\mathrm{O}_{2}, \mathrm{NO}_{2}+\mathrm{H}_{2} \rightleftharpoons \mathrm{HNO}_{2}+\mathrm{H}, \mathrm{HNO}_{2}(+\mathrm{M}) \rightleftharpoons \mathrm{HONO}(+\mathrm{M}), \mathrm{HNO}_{2}+\mathrm{OH} \rightleftharpoons \mathrm{NO}_{2}+\mathrm{H}_{2} \mathrm{O}\right)$ and confirmed that the $\mathrm{HNO}_{2}$ isomer $\mathrm{HONO}$, is formed the via same reaction channel. They further discussed that $\mathrm{HNO}_{2}$ may act as an $\mathrm{OH}$ sink through the reaction $\mathrm{HNO}_{2}+\mathrm{OH} \rightleftharpoons \mathrm{NO}_{2}+\mathrm{H}_{2} \mathrm{O}$ inhibiting the system reactivity. Furthermore it may isomerize to $\mathrm{HONO}$ and decompose to $\mathrm{NO}$ and $\mathrm{OH}$. The latter case is confirmed by the simulation results in our present study. Therefore we have adopted the rate parameters from the work of Rasmussen et al..$^{53}$. The direct reaction of $\mathrm{NO}_{2}$ with $\mathrm{H}_{2}$ has two routes forming $\mathrm{HONO}+\mathrm{H} / \mathrm{HNO}_{2}+\mathrm{H}$ which was proposed in ${ }^{53}$. The reaction $\mathrm{NO}_{2}+\mathrm{H}_{2}$ $\rightleftharpoons \mathrm{HONO}+\mathrm{H}$ appeared in the sensitivity analysis for the ignition delay time in the work of Mathieu et al. $^{63}$ and also in this work (see Figure 4). The rate constants of these reactions $\left(\mathrm{NO}_{2}+\mathrm{H}_{2}=\mathrm{HONO}+\mathrm{H} / \mathrm{HNO} 2+\mathrm{H}\right)$ are also adopted from Rasmussen et al. ${ }^{53}$.

\section{$\mathrm{N}_{2} \mathrm{O}$ sub-mechanism:}

$\mathrm{N}_{2} \mathrm{O}$ is an important intermediate in the thermal $\mathrm{DeNO}_{x}$ process ${ }^{70}$ which is mainly formed through the amine radical $\mathrm{NH}+\mathrm{NO} \rightleftharpoons \mathrm{N}_{2} \mathrm{O}+\mathrm{H}$. Another potential route for $\mathrm{N}_{2} \mathrm{O}$ formation is $\mathrm{NH}_{2}+\mathrm{NO}_{2} \rightleftharpoons \mathrm{N}_{2} \mathrm{O}+\mathrm{H}_{2} \mathrm{O} . \mathrm{N}_{2} \mathrm{O}$ can also work as an oxidizing agent ${ }^{56,71-74}$ which dissociates to produce $\mathrm{O}$ atoms via $\mathrm{N}_{2} \mathrm{O}(+\mathrm{M}) \rightleftharpoons \mathrm{N}_{2}+\mathrm{O}(+\mathrm{M})$. The backward of this reaction becomes significant under lean and high pressure conditions, and opens an alternative pathway to NO formation. Atomic oxygen further takes part in the chain branching step $\mathrm{H}_{2}+\mathrm{O} \rightleftharpoons \mathrm{H}+\mathrm{OH}$ increasing the radical pool. The reaction $\left(\mathrm{N}_{2} \mathrm{O}(+\mathrm{M}) \rightleftharpoons \mathrm{N}_{2}+\mathrm{O}(+\mathrm{M})\right)$ is also one of the channels consuming $\mathrm{N}_{2} \mathrm{O}$ in the thermal DeNOx process ${ }^{70}$. We have adopted the rate constant of this reaction from the work of 
Röhrig et al. ${ }^{54}$ who studied the pressure dependence of the thermal decomposition of $\mathrm{N}_{2} \mathrm{O}$ in shock tube experiments in the pressure range of $0.3-450 \mathrm{~atm}$ and at temperatures ranging from 1570$3100 \mathrm{~K}$. The reaction $\mathrm{N}_{2} \mathrm{O}+\mathrm{H} \rightleftharpoons \mathrm{N}_{2}+\mathrm{OH}$ is another important reaction in the $\mathrm{N}_{2} \mathrm{O}$ chemistry. This reaction competes with the reaction $\mathrm{N}_{2} \mathrm{O}+\mathrm{H} \rightleftharpoons \mathrm{NH}+\mathrm{NO}$ for the consumption of $\mathrm{H}$ atoms. Powell et al. ${ }^{72}$ studied the laminar flame speeds of $\mathrm{H}_{2} / \mathrm{N}_{2} \mathrm{O}$ and $\mathrm{C}_{1}-\mathrm{C}_{3} / \mathrm{N}_{2} \mathrm{O}$ mixtures. They adopted the kinetic scheme of Allen et al. $1998{ }^{45}$ to perform an accompanying numerical study. Here they modified the rate parameter of $\mathrm{N}_{2} \mathrm{O}+\mathrm{H} \rightleftharpoons \mathrm{N}_{2}+\mathrm{OH}$ for a better match with their measurements. In their subsequent study Powell et al..$^{55}$ performed a kinetic model evaluation on a large set of published experimental data (ignition delay times obtained in shock tubes, speciation in a burner stabilized flame, speciation in a flow reactor) and their own previous work (laminar flame speeds) with a large fraction of $\mathrm{N}_{2} \mathrm{O}$ in the reactant mixture. They found the reaction $\mathrm{N}_{2} \mathrm{O}+\mathrm{H}^{\rightleftharpoons} \rightleftharpoons \mathrm{N}_{2}+\mathrm{OH}$ as one of the most important and sensitive reactions for accurately predicting the wide set of experimental data which they considered. Powell et al. ${ }^{55}$ modified their previous rate parameters 72 to best match the range of experimental data taken into consideration. In our present study we have adopted the rate parameters for the reaction $\left(\mathrm{N}_{2} \mathrm{O}+\mathrm{H} \rightleftharpoons \mathrm{N}_{2}+\mathrm{OH}\right)$ from the work of Powell et al. ${ }^{55}$ and this rate constant value is within the uncertainty of a factor 2 of the rate constant recommended by Baulch et al. ${ }^{29}$. We also find this reaction to be highly sensitive in predicting the $\mathrm{H}_{2} / \mathrm{N}_{2} \mathrm{O}$ laminar flame speed (Figure S2), ignition delay times (Figure S5 and Figure S7) and predicting the speciation in a burner stabilized flame (Figure S23).

Other reactions in the $\mathrm{N}_{2} \mathrm{O}$ sub-scheme which are of particular interest are the reactions of $\mathrm{N}_{2} \mathrm{O}$ with $\mathrm{O}$ atoms:

$\mathrm{N}_{2} \mathrm{O}+\mathrm{O} \rightleftharpoons \mathrm{NO}+\mathrm{NO}$ 
$\mathrm{N}_{2} \mathrm{O}+\mathrm{O} \rightleftharpoons \mathrm{N}_{2}+\mathrm{O}_{2}$.

In a burner stabilized flame (Figure 10) where $\mathrm{N}_{2} \mathrm{O}$ is present in the reactant mixture as an oxidizing agent the NO formation is mainly controlled by the branching ratio between these two reactions. In our present work we have adopted the rate constants of these reactions from the recommendation of Baulch et al. ${ }^{29}$. The $\mathrm{O}$ atom of $\mathrm{N}_{2} \mathrm{O}$ can be abstracted when reacting with $\mathrm{OH}$ and $\mathrm{NO}$ to form $\mathrm{N}_{2}+\mathrm{HO}_{2}$ and $\mathrm{NO}_{2}+\mathrm{N}_{2}$. Rate parameters of these reactions are adopted following the suggestion of Mebel et al. ${ }^{75}$, who calculated rate constants using ab initio transition state theory. The rate constant of the reaction $\mathrm{N}_{2} \mathrm{O}+\mathrm{N} \rightleftharpoons \mathrm{N}_{2}+\mathrm{NO}$ is taken from Mathieu et al. ${ }^{17}$. Mevel et al. ${ }^{76}$ and Mathieu et al. ${ }^{17,77}$ suggested that inclusion of the excited hydroxyl radical $\left(\mathrm{OH}^{*}\right)$ in the mechanism, particularly for the reaction $\mathrm{N}_{2} \mathrm{O}+\mathrm{H} \rightleftharpoons \mathrm{N}_{2}+\mathrm{OH}^{*}$, improves predictions for the calculated ignition delay times compared to using the ground state $\mathrm{OH}$ radical. Mevel et al. ${ }^{76}$ and Mathieu et al. ${ }^{17}$ compared there experimentally determined $\mathrm{OH}^{*}$ profile with the numerically predicted $\mathrm{OH}^{*}$ formation profile and found a good agreement. They also showed the difference when using the ground state $\mathrm{OH}$ profile. Following there suggestion we included this reaction $\left(\mathrm{N}_{2} \mathrm{O}+\mathrm{H} \rightleftharpoons \mathrm{N}_{2}+\mathrm{OH}^{*}\right)$ in our scheme adopting the rate parameter from the experimental work of Hidaka et al. ${ }^{56}$ who performed a $\mathrm{OH}^{*}$ chemiluminescence study in $\mathrm{N}_{2} \mathrm{O} / \mathrm{H}_{2} / \mathrm{Ar}$ mixtures in a shock tube at $2 \mathrm{~atm}$.

\section{$\mathrm{NO}_{3}$ sub-mechanism:}

The only $\mathrm{NO}_{3}$ formation routes are via reactions $\mathrm{NO}_{2}+\mathrm{O}(+\mathrm{M}) \leftrightharpoons \mathrm{NO}_{3}$ and $\mathrm{NO}_{2}+\mathrm{NO}_{2} \leftrightharpoons \mathrm{NO}_{3}+\mathrm{NO}$. In our present study the inclusion or exclusion of the $\mathrm{NO}_{3}$ reaction scheme does not have any significant effect on predicted ignition delay times, speciation in flow a reactor and a jet stirred reactor for the $\mathrm{H}_{2} / \mathrm{O}_{2} / \mathrm{NO}_{\mathrm{x}}$ system. However, this subset is included for the sake of completeness

of the kinetic scheme. The $\mathrm{NO}_{3}$ reaction sub-mechanism is adopted from the model of Mendiara 
and Glarborg ${ }^{60}$ who studied the effect of $\mathrm{CO}_{2}$ concentration on the ammonia oxidation during oxy-fuel combustion of methane in a flow reactor at atmospheric pressure and temperatures ranging from 973-1773 K. Additionally the reactions $\mathrm{NO}_{3}+\mathrm{NO}_{3} \leftrightharpoons \mathrm{NO}_{2}+\mathrm{NO}_{2}+\mathrm{O}_{2}$ and $\mathrm{NO}_{3}+\mathrm{HO}_{2} \leftrightharpoons \mathrm{HNO}_{3}+\mathrm{O}_{2}$, not considered by Mendiara and Glarborg ${ }^{60}$, were included in our present

work. The rate parameters of these two addition reactions were adopted from Coppens et al. ${ }^{47}$ who measured the laminar burning velocity of $\mathrm{CH}_{4} / \mathrm{H}_{2} / \mathrm{O}_{2} / \mathrm{N}_{2}$ mixtures at varying $\mathrm{H}_{2}$ fractions in a heat flux burner and NO formation in the studied flames.

\section{$\mathrm{HNO}_{3}$ sub-mechanism:}

In the flow analysis for the $\mathrm{H}_{2} / \mathrm{O}_{2} / \mathrm{NO}_{\mathrm{x}}$ system in jet stirred and flow reactors we observe that a small amount of $\mathrm{HNO}_{3}$ is formed via the reaction $\mathrm{NO}+\mathrm{HO}_{2}+\mathrm{M} \leftrightharpoons \mathrm{HNO}_{3}+\mathrm{M}$. The formed $\mathrm{HNO}_{3}$ dissociates to $\mathrm{NO}_{2}$ and $\mathrm{OH}$ via the reaction $\mathrm{NO}_{2}+\mathrm{OH}(+\mathrm{M}) \leftrightharpoons \mathrm{HNO}_{3}(+\mathrm{M})$ which participates in the $\mathrm{NO} / \mathrm{NO}_{2}$ interconversion process. Other reaction channels that are involved in $\mathrm{HNO}_{3}$ consumption are the reactions with $\mathrm{H}, \mathrm{OH}$ and $\mathrm{NH}_{2}$ radicals. The complete $\mathrm{HNO}_{3}$ reaction scheme is adopted from the kinetic model of Coppens et al. ${ }^{47}$.

\section{$\mathrm{NH}_{3}$ sub-mechanism:}

The thermal decomposition of $\mathrm{NH}_{3}$ features two product channels forming $\mathrm{NH}_{2}$ and $\mathrm{H}$ radicals as the major route and $\mathrm{NH}$ and $\mathrm{H}_{2}$ as the minor pathway. The rate parameters have been adopted from the compilation of Baulch et al. ${ }^{29}$. In our scheme we have introduced the pressure dependent rate parameters for the thermal decomposition reaction of $\mathrm{NH}_{3}$ in the TROE format which is not included in other published models $15,17,47,49,78,79$. Hydrogen abstraction from $\mathrm{NH}_{3}$ occurs in reactions with $\mathrm{H}, \mathrm{O}, \mathrm{OH}$ and $\mathrm{HO}_{2}$ radicals mainly forming the $\mathrm{NH}_{2}$ radical. The $\mathrm{NH}_{3}+\mathrm{H} / \mathrm{OH} \leftrightharpoons \mathrm{NH}_{2}+\mathrm{H}_{2} / \mathrm{O}$ reaction rate parameters are adopted from the modeling work of Klaus 
$1997^{48}$ who performed a detailed kinetic modeling study of $\mathrm{NO}_{\mathrm{x}}$ formation in a burner stabilized flame for $\mathrm{NH}_{3}$ and $\mathrm{C}_{1}-\mathrm{C}_{4}$ hydrocarbons. The $\mathrm{NH}_{3}+\mathrm{O} \leftrightharpoons \mathrm{NH}_{2}+\mathrm{OH}$ rate parameters are adopted from Baulch et al. ${ }^{29}$. Kinetic data for the $\mathrm{NH}_{3}+\mathrm{HO}_{2} \leftrightharpoons \mathrm{NH}_{2}+\mathrm{H}_{2} \mathrm{O}_{2}$ reaction rate are taken from the kinetic model of Skreiberg et al. ${ }^{51}$ who a performed kinetic study of ammonia oxidation in a flow reactor based on experiments by Hasegawa and Sato ${ }^{80}$. The reaction $\mathrm{NH}_{3}+\mathrm{NH}_{2} \leftrightharpoons \mathrm{N}_{2} \mathrm{H}_{3}+\mathrm{H}_{2}$ and its kinetic data are adopted from the model of Coppens et al. ${ }^{47}$.

\section{NH2 sub-mechanism:}

This sub-mechanism is an important part of the $\mathrm{DeNO}_{x}$ process where $\mathrm{NH}_{3}$ is used as reducing agent. The reaction rate for hydrogen abstraction from $\mathrm{NH}_{2}$ via $\mathrm{H}$ atoms, which forms $\mathrm{NH}$ and $\mathrm{H}_{2}$, is adopted from Baulch et al. ${ }^{29}$. The rate constant of this reaction $\left(\mathrm{NH}_{2}+\mathrm{H} \leftrightharpoons \mathrm{NH}+\mathrm{H}_{2}\right)$ is decreased by $12 \%$ to better predict the ammonia flame speed, which is within the given uncertainty range. The reaction of $\mathrm{NH}_{2}$ with $\mathrm{O}$ atoms has three product channels $\left(\mathrm{HNO}+\mathrm{H} / \mathrm{NH}+\mathrm{OH} / \mathrm{NO}+\mathrm{H}_{2}\right)$ whose rate parameters are adopted from the kinetic model of Klaus $1997^{48}$. The rate constant of $\mathrm{NH}_{2}+\mathrm{OH} \leftrightharpoons \mathrm{NH}+\mathrm{H}_{2} \mathrm{O}$ is also taken from the modeling work of Klaus $1997^{48}$. The reaction of $\mathrm{HO}_{2}$ with $\mathrm{NH}_{2}$ has two product channels forming $\mathrm{H}_{2} \mathrm{NO}+\mathrm{OH}$ and $\mathrm{NH}_{3}+\mathrm{O}_{2}$. Similarly, $\mathrm{O}_{2}$ reacts with $\mathrm{NH}_{2}$ forming $\mathrm{H}_{2} \mathrm{NO}+\mathrm{O}$ and $\mathrm{HNO}+\mathrm{OH}$ with the first channel being the major path ${ }^{49}$. The rate parameters of these reactions are adopted from the kinetic scheme of Skreiberg et al. ${ }^{51}$. In our present study, these reactions are less sensitive compared to other reactions in the $\mathrm{NH}_{2}$ submechanism. The reaction of $\mathrm{NH}_{2}$ with $\mathrm{NO}$ which is chain branching in the channel to $\mathrm{NNH}+\mathrm{OH}$ and chain terminating in the channel to $\mathrm{N}_{2}+\mathrm{H}_{2} \mathrm{O}$ is very important in the thermal $\mathrm{DeNO}_{x}$ process ${ }^{3,70}$. The rate parameters of these two reactions have been adopted from the study of Miller and

Glarborg ${ }^{3}$ who obtained the total rate constant value by fitting the channel branching in simulations of published experimental data. However, the rate constants used in this work are 
increased by $65 \%$ in order to better match the wide range of published experimental data considered in the mechanism validation. The reaction $\mathrm{NH}_{2}+\mathrm{NO}_{2}$ has two product channels forming $\mathrm{H}_{2} \mathrm{NO}+\mathrm{NO}$ and $\mathrm{N}_{2} \mathrm{O}+\mathrm{H}_{2} \mathrm{O}$. Glarborg et al. ${ }^{81}$ studied the $\mathrm{NH}_{3} / \mathrm{NO}_{2}$ system in a flow reactor and concluded that the $\mathrm{NH}_{2}+\mathrm{NO}_{2}$ reaction forming $\mathrm{H}_{2} \mathrm{NO}+\mathrm{NO}$ is the more important channel recycling $\mathrm{NO}_{2}$ back to NO. The importance of this reaction was again emphasized by Miller and Glarborg ${ }^{3}$ in their experimental and modeling study of $\mathrm{H}_{2} / \mathrm{CO} / \mathrm{NO}_{\mathrm{x}}$ combustion in a flow reactor. In our present work we adopt the rate parameters of these reactions from the experimental work of Park and $\mathrm{Lin}^{50}$ who performed a mass spectrometric study of the $\mathrm{NH}_{2}+\mathrm{NO}_{2}$ reaction in the temperature range of 300-910 K . Additionally the reaction $\mathrm{NH}_{2}+\mathrm{NO} \leftrightharpoons \mathrm{N}_{2} \mathrm{O}+\mathrm{H}_{2}$ is included in our present work whose rate constant is adopted from the kinetic model of Duynslaegher et al. ${ }^{14}$ who performed a modeling study of $\mathrm{NH}_{3}$ oxidation in a burner stabilized low pressure premixed flame.

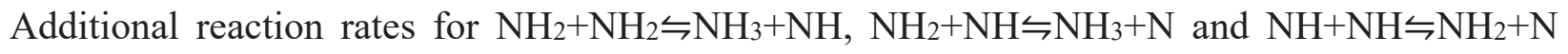
are adopted from Klippenstein et al..$^{52}$, who calculated rate parameters using ab initio transition state theory. The reaction $\mathrm{NH}_{2}+\mathrm{N} \leftrightharpoons \mathrm{N}_{2}+\mathrm{H}+\mathrm{H}$ which is not included in kinetic schemes of $3,15,51,52,78$ is here adopted from the kinetic model of Klaus $1997^{48}$. The reaction rate constants for the reactions $\mathrm{NH}_{2}+\mathrm{HNO} \leftrightharpoons \mathrm{NH}_{3}+\mathrm{NO}$ and $\mathrm{NH}_{2}+\mathrm{HONO} \leftrightharpoons \mathrm{NH}_{3}+\mathrm{NO}_{2}$ are adopted from Mebel et al. ${ }^{82}$, who calculated rate constants using ab initio molecular orbital theory.

\section{NH sub-mechanism:}

The rate parameters of hydrogen abstraction from $\mathrm{NH}$ by $\mathrm{H}$ atoms forming $\mathrm{N}$ and $\mathrm{H}_{2}$ are adopted from Baulch et al. ${ }^{29}$ and decreased by $33 \%$ which is within the given uncertainty. The reaction $\mathrm{NH}+\mathrm{O}$ has two product channels $(\mathrm{NO}+\mathrm{H}$ and $\mathrm{N}+\mathrm{OH})$. The reaction forming $\mathrm{NO}$ is the dominant path while the channel forming $\mathrm{N}+\mathrm{OH}$ is usually not included in published mechanisms ${ }^{15,17,49,51,78}$. We found this channel to be important and included it in our kinetic scheme. The rate parameters 
for the reaction $\mathrm{NH}+\mathrm{O} \leftrightharpoons \mathrm{NO}+\mathrm{H}$ are adopted from the modeling work of Klaus $1997{ }^{48}$ while the rate constant of the $\mathrm{NH}+\mathrm{O} \leftrightharpoons \mathrm{N}+\mathrm{OH}$ reaction is adopted from the kinetic scheme of Duynslaegher et al. ${ }^{14}$ and reduced by $50 \%$ for improving the model predictions. The reaction of $\mathrm{OH}$ with $\mathrm{NH}$ has three routes forming $\mathrm{HNO}+\mathrm{H}, \mathrm{NO}+\mathrm{H}_{2}$ and $\mathrm{N}+\mathrm{H}_{2} \mathrm{O}$ respectively. However, in the models from $15,17,49,78$ the second channel $\left(\mathrm{NH}+\mathrm{OH} \leftrightharpoons \mathrm{NO}+\mathrm{H}_{2}\right)$ is not included. The rate parameters of these reactions are adopted from the kinetic model of Klaus $1997{ }^{48}$. The rate constant of the $\mathrm{NH}+\mathrm{O}_{2}$ reaction forming $\mathrm{HNO}+\mathrm{O}$ and $\mathrm{NO}+\mathrm{OH}$ is taken from the model of ${ }^{49}$. For the reactions $\mathrm{NH}+\mathrm{N} \leftrightharpoons \mathrm{N}_{2}+\mathrm{H}, \quad \mathrm{NH}+\mathrm{NO} \leftrightharpoons \mathrm{N}_{2}+\mathrm{OH}, \quad \mathrm{NH}+\mathrm{NO}_{2} \leftrightharpoons \mathrm{N}_{2} \mathrm{O}+\mathrm{OH}, \quad \mathrm{NH}+\mathrm{NO}_{2} \leftrightharpoons \mathrm{HNO}+\mathrm{NO}, \quad$ and $\mathrm{NH}+\mathrm{HONO} \leftrightharpoons \mathrm{NH}_{2}+\mathrm{NO}_{2}$ kinetic data is taken from Klippenstein et al. ${ }^{49}$ They studied the role of $\mathrm{NNH}$ in NO formation and reduction. In particular their theoretical study focused on the reaction systems of $\mathrm{NNH}+\mathrm{O}, \mathrm{NNH}+\mathrm{O}_{2}$ and $\mathrm{NH}_{2}+\mathrm{O}_{2}$ using ab initio transition state theory. In addition they provided rate constants for the $\mathrm{NH}+\mathrm{NO}$ and $\mathrm{O}+\mathrm{N}_{2} \mathrm{O}$ reaction. They concluded that in the thermal DeNOx process, the role of the $\mathrm{NH}_{2}+\mathrm{NO}$ reaction system is significant. Their mechanism is based on the above mentioned study by Miller and Glarborg ${ }^{3}$. They ${ }^{49}$ validated their model against the published experimental data with emphasis on flow reactor experiments. In their discussion they stated that $\mathrm{NH}$ is formed via reactions involving $\mathrm{NH}_{2}$, particularly $\mathrm{NH}_{2}+\mathrm{OH} \leftrightharpoons \mathrm{NH}+\mathrm{H}_{2} \mathrm{O}$. The formed $\mathrm{NH}$ is partially oxidized to $\mathrm{NO}$ via the $\mathrm{NH}+\mathrm{O}_{2}$ reaction. In addition, they concluded that the $\mathrm{NH}+\mathrm{NO}$ reaction forming $\mathrm{NNH}$ is a minor channel contributing to $\mathrm{NO}$ formation. Finally, we included the reaction $\mathrm{NH}+\mathrm{N}_{2} \mathrm{O} \leftrightharpoons \mathrm{N}_{2}+\mathrm{HNO}$ and took the kinetic data from the model by Duynslaegher et al. ${ }^{14}$.

\section{NNH sub-mechanism:}

The NNH sub-mechanism is compiled adopting the rate parameter and reactions from Klippenstein et al. ${ }^{49}$, Miller and Glarborg ${ }^{3}$, Glarborg et al..$^{58}$ and Allen et al. ${ }^{12}$. Miller and Glarborg ${ }^{3}$ proposed 
the $\mathrm{NNH}$ consumption through $\mathrm{NNH} \leftrightharpoons \mathrm{N}_{2}+\mathrm{H}$ and $\mathrm{NNH}+\mathrm{O}_{2} \leftrightharpoons \mathrm{N}_{2}+\mathrm{HO}_{2}$. In the study of Kasuya and Glarborg ${ }^{83}$ a higher amount of $\mathrm{NO}_{2}$ was detected at higher $\mathrm{O}_{2}$ concentrations which allowed them (Miller and Glarborg ${ }^{3}$ ) to consider $\mathrm{NNH}+\mathrm{O}_{2} \leftrightharpoons \mathrm{N}_{2}+\mathrm{HO}_{2}$ as the major channel for $\mathrm{NNH}$ consumption. Based on theoretical and experimental studies from the literature they considered a $\mathrm{NNH}$ life time of $1.5 \times 10^{-8} \mathrm{~s}$ and thus derived the $\mathrm{NNH} \leftrightharpoons \mathrm{N}_{2}+\mathrm{H}$ rate constant of $6.27 \times 10^{7} / \mathrm{s}$. Details on the lifetime of the NNH radical were discussed in the work of Klippenstein et al. ${ }^{49}$. They assumed the NNH life time to be $10^{-9} \mathrm{~s}$ and derived the rate constant of $\mathrm{NNH} \leftrightharpoons \mathrm{N}_{2}+\mathrm{H}$ to be $1.0 \times 10^{9}$ /s which is around a factor 15 higher than proposed by Miller and Glarborg ${ }^{3}$. In our present work we have adopted the rate constant value from the kinetic model of Miller and Glarborg ${ }^{3}$ which gives better results especially for laminar flame speeds of $\mathrm{NH}_{3}$. The reaction of $\mathrm{NNH}+\mathrm{O}_{2}$ features two channels: $\mathrm{N}_{2}+\mathrm{HO}_{2}$ and $\mathrm{N}_{2}+\mathrm{H}+\mathrm{O}_{2}$, the former being the major channel with a branching ratio of $80 \%$ (see ref. ${ }^{3}$ ). The rate parameters of these reactions have been adopted from the kinetic scheme of Glarborg et al. ${ }^{58}$. The recombination reaction of $\mathrm{NNH}$ forming $\mathrm{N}_{2} \mathrm{H}_{2}$ $\left(\mathrm{NNH}+\mathrm{NNH} \leftrightharpoons \mathrm{N}_{2} \mathrm{H}_{2}+\mathrm{H}_{2}\right)$, which is not included in work of Miller and Glarborg ${ }^{3}$ and Klippenstein et al. ${ }^{49}$, is included in the present work for the completeness of the mechanism adopting the rate parameters from Allen et al. ${ }^{12}$. NNH is also consumed by the attack of $\mathrm{H}, \mathrm{OH}, \mathrm{NO}, \mathrm{NH}$, and $\mathrm{NH}_{2}$ radicals mainly forming $\mathrm{N}_{2}$ as major product. The reaction $\mathrm{NNH}+\mathrm{O}$ has three product channels forming $\mathrm{N}_{2}+\mathrm{OH}, \mathrm{NH}+\mathrm{NO}$ and $\mathrm{N}_{2} \mathrm{O}+\mathrm{H}$ and the rate parameters of these reactions are adopted from Klippenstein et al. ${ }^{49}$.

\section{$\mathbf{N}_{2} \mathrm{H}_{2} / \mathrm{H}_{2} \mathbf{N N} / \mathbf{N}_{2} \mathrm{H}_{3} / \mathbf{N}_{2} \mathrm{H}_{4}$ sub-mechanism:}

The sub-mechanism of $\mathrm{N}_{2} \mathrm{H}_{2}, \mathrm{~N}_{2} \mathrm{H}_{3}, \mathrm{~N}_{2} \mathrm{H}_{4}$ and $\mathrm{H}_{2} \mathrm{NN}$ has been largely taken from the kinetic models of Skreiberg et al. ${ }^{51}$, Allen et al. ${ }^{12}$, Coppens et al. ${ }^{47}$, Klaus $1997^{48}$ and Klippenstein et al. ${ }^{52}$. Allen et al. ${ }^{12}$ studied the combustion of $\mathrm{CO} / \mathrm{N}_{2} \mathrm{O} / \mathrm{H}_{2} \mathrm{O} / \mathrm{N}_{2}$ mixtures in a flow reactor in a pressure 
range of 3-15 atm and a temperature range of 950-1123 K. They used the experimentally measured species profiles as reference for deriving a detailed kinetic model for $\mathrm{CO} / \mathrm{N}_{2} \mathrm{O}$ interaction. In their later study ${ }^{45}$ they showed and discussed the importance of $\mathrm{N}_{2} \mathrm{H}_{\mathrm{x}}$ chemistry for predicting the speciation in the performed flow reactor experiments. In this work we show the effect of $\mathrm{N}_{2} \mathrm{H}_{\mathrm{x}}$ chemistry on $\mathrm{NH}_{3}$ laminar flame speed in Figure 1.

\section{$\mathrm{NH}_{2} \mathrm{OH}$ sub-mechanism:}

The complete $\mathrm{NH}_{2} \mathrm{OH}$ sub-mechanism is adopted from the work of Klippenstein et al. ${ }^{52}$ who investigated the thermal decomposition of $\mathrm{NH}_{2} \mathrm{OH}$ in a combined experimental (shock tube) and theoretical study. In their experiments they measured the $\mathrm{OH}$ radical time histories over the temperature range of $1355-1889 \mathrm{~K}$ and their predicted $\mathrm{OH}$ profile was in good agreement with experimental $\mathrm{OH}$ profile. They concluded that $\mathrm{NH}_{2} \mathrm{OH}$ decomposes to $\mathrm{NH}_{2}$ and $\mathrm{OH}$ representing the major route while the formation of $\mathrm{NH}_{3}+\mathrm{O}$ is a minor channel and can be neglected. Using ab initio transition state theory they derived the rate constants of other elementary reactions of relevance for the $\mathrm{NH}_{2} \mathrm{OH}$ sub-mechanism. The reaction $\mathrm{HNOH}+\mathrm{HNO} \leftrightharpoons \mathrm{NH}_{2} \mathrm{OH}+\mathrm{NO}$, which was not included in their mechanism, is adopted from Coppens et al. ${ }^{47}$.

\section{HNO sub-mechanism:}

The HNO sub-mechanism is compiled mainly from the work of Rasmussen et al. ${ }^{53}$, Skreiberg et al. ${ }^{51}$, Glarborg et al. ${ }^{58}$, Klaus $1997^{48}$ and Coppens et al..$^{47}$. The hydrogen abstraction reactions from $\mathrm{HNO}$ by $\mathrm{H}, \mathrm{O}, \mathrm{OH}$ and $\mathrm{O}_{2}$ forming $\mathrm{NO}+\mathrm{H}_{2} / \mathrm{OH} / \mathrm{H}_{2} \mathrm{O} / \mathrm{HO}_{2}$ respectively are adopted from the ammonia oxidation modeling work of Skreiberg et al. ${ }^{51}$. The recombination reaction $\mathrm{HNO}+\mathrm{HNO} \leftrightharpoons \mathrm{N}_{2} \mathrm{O}+\mathrm{H}_{2} \mathrm{O}$ is adopted from the model of Glarborg et al. ${ }^{58}$, who performed an experimental and kinetic modeling study of $\mathrm{C}_{1} / \mathrm{C}_{2}$ hydrocarbon interaction with $\mathrm{NO}_{\mathrm{x}}$ in a flow 
reactor. The reactions $\mathrm{HNO}+\mathrm{N} \leftrightharpoons \mathrm{NO}+\mathrm{NH}$ and $\mathrm{HNO}+\mathrm{NO} \leftrightharpoons \mathrm{N}_{2} \mathrm{O}+\mathrm{OH}$ and its rate constants are adopted from the kinetic model of Klaus $1997^{48}$ while the reactions $\mathrm{HNO}+\mathrm{N} \leftrightharpoons \mathrm{N}_{2} \mathrm{O}+\mathrm{H}$, $\mathrm{HNO}+\mathrm{NH} \leftrightharpoons \mathrm{NH}_{2}+\mathrm{NO}$ are adopted from Coppens et al. ${ }^{47}$. Those reactions that we adopted from 47,48 were not included in the kinetic schemes of ${ }^{15,49,53,78}$ and we included these reactions in our scheme for the completeness of the kinetic model. The rate parameters of the reaction of HNO with $\mathrm{NO}_{2}$ forming $\mathrm{HONO}+\mathrm{NO}$ and the thermal decomposition reaction of $\mathrm{HNO}$ forming $\mathrm{NO}+\mathrm{H}$ are taken from the kinetic scheme of Rasmussen et al. ${ }^{53}$.

\section{HON sub-mechanism:}

The complete HON sub-mechanism is adopted from the kinetic model of Mathieu et al. ${ }^{17}$. They performed an experimental and modeling study of ammonia oxidation in a shock tube spanning wide ranges of pressure, temperature and fuel-oxidizer ratio. In their model HON is mainly formed via the combination reaction $\mathrm{NO}+\mathrm{H}+\mathrm{M} \leftrightharpoons \mathrm{HON}+\mathrm{M}$. $\mathrm{HON}$ is consumed via the reactions: $\mathrm{HON}+\mathrm{H} \leftrightharpoons \mathrm{HNO}+\mathrm{H}, \quad \mathrm{HON}+\mathrm{H} \leftrightharpoons \mathrm{NH}+\mathrm{OH}, \quad \mathrm{HON}+\mathrm{O} \leftrightharpoons \mathrm{OH}+\mathrm{NO}, \quad \mathrm{HON}+\mathrm{OH} \leftrightharpoons \mathrm{HONO}+\mathrm{H}$ and $\mathrm{HON}+\mathrm{O}_{2} \leftrightharpoons \mathrm{NO}_{2}+\mathrm{OH}$. Among these reactions, $\mathrm{HON}+\mathrm{H}$ is important for $\mathrm{NO}$ formation and consumption via HNO. The reaction forming $\mathrm{HNO}+\mathrm{H}$ (which is an isomerization) is the dominating channel (branching ratio $\sim 70 \%$ ) and the formed HNO reacts with NO to yield $\mathrm{NH}+\mathrm{NO}_{2}\left(\mathrm{NH}+\mathrm{NO}_{2} \leftrightharpoons \mathrm{HNO}+\mathrm{NO}\right)$. Another route $(\mathrm{HON}+\mathrm{H} \leftrightharpoons \mathrm{NH}+\mathrm{OH})$ which directly forms the amine radical, also has a NO reduction potential by contributing to the amine radical pool.

\section{$\mathrm{H}_{2} \mathrm{NO}$ sub-mechanism:}

The $\mathrm{H}_{2} \mathrm{NO}$ chemistry is an important part of the thermal DeNOx mechanism ${ }^{3} . \mathrm{H}_{2} \mathrm{NO}$ is mainly formed by reactions of the amine radical $\left(\mathrm{NH}_{2}\right)$ :

$\mathrm{NH}_{2}+\mathrm{O}_{2} \leftrightharpoons \mathrm{H}_{2} \mathrm{NO}+\mathrm{O}$ 
$\mathrm{NH}_{2}+\mathrm{HO}_{2} \leftrightharpoons \mathrm{H}_{2} \mathrm{NO}+\mathrm{OH}$

$\mathrm{NH}_{2}+\mathrm{NO}_{2} \leftrightharpoons \mathrm{H}_{2} \mathrm{NO}+\mathrm{NO}$.

Klippenstein et al. ${ }^{49}$ performed a numerical analysis of the $\mathrm{NH}_{2}+\mathrm{O}_{2}$ reaction and confirmed that the $\mathrm{H}_{2} \mathrm{NO}$ formation route is the dominant path which competes with the $\mathrm{HNO}+\mathrm{OH}$ channel. Similarly, $\mathrm{NH}_{2}+\mathrm{NO}_{2}$ has two product channels forming $\mathrm{N}_{2} \mathrm{O}+\mathrm{H}_{2} \mathrm{O}$ and $\mathrm{H}_{2} \mathrm{NO}+\mathrm{NO}$, the former being the major product $3,49,84$ with $80 \%$ branching ratio. The formed $\mathrm{H}_{2} \mathrm{NO}$ either dissociates unimoleculary to $\mathrm{HNO}+\mathrm{H}$ or is attacked by $\mathrm{H}, \mathrm{O}, \mathrm{OH}, \mathrm{HO}_{2}, \mathrm{NO}$ and $\mathrm{NH}_{2}$ radicals forming $\mathrm{HNO}$ and the corresponding products. The reaction of $\mathrm{H}_{2} \mathrm{NO}$ with $\mathrm{H}$ atoms has another possible channel forming $\mathrm{NH}_{2}+\mathrm{OH}$. If this route is fast enough to produce $\mathrm{NH}_{2}$ then the amine radical pool will take part in the $\mathrm{NO}$ reduction process via the reaction $\mathrm{NH}_{2}+\mathrm{NO} \leftrightharpoons \mathrm{N}_{2}+\mathrm{H}_{2} \mathrm{O} / \mathrm{NNH}+\mathrm{OH}$. $\mathrm{H}_{2} \mathrm{NO}$ can also react with $\mathrm{O}_{2}$ and $\mathrm{NO}_{2}$ forming $\mathrm{HNO}+\mathrm{HO}_{2}$ and $\mathrm{HONO}+\mathrm{HNO}$, respectively. The $\mathrm{H}_{2} \mathrm{NO}$ submechanism is adopted from the kinetic model of Glarborg et al. ${ }^{59}$ who performed flow reactor experiments on reduction of $\mathrm{NO}$ by $\mathrm{CO}$ and $\mathrm{H}_{2}$ under fuel rich conditions in the temperature range of $1200-1800 \mathrm{~K}$. In their study they found that the $\mathrm{H}_{2} \mathrm{NO}$ chemistry was not a significant contributor in reducing NO.

\section{HNOH sub-mechanism:}

$\mathrm{HNOH}$ is an isomer of $\mathrm{H}_{2} \mathrm{NO}$ which is mainly formed via the recombination reaction $\mathrm{HNO}+\mathrm{H}+\mathrm{M} \leftrightharpoons \mathrm{HNOH}+\mathrm{M}$. $\mathrm{HNOH}$ is consumed in reactions with $\mathrm{H}, \mathrm{O}, \mathrm{OH}, \mathrm{HO}_{2}, \mathrm{NH}_{2}, \mathrm{O}_{2}$ and $\mathrm{NO}_{2}$ mainly forming $\mathrm{HNO}$ and $\mathrm{NH}_{2}$. The reaction $\mathrm{HNOH}+\mathrm{H} \leftrightharpoons \mathrm{NH}_{2}+\mathrm{OH}$ is of particular importance because of its direct contribution to the amine radical pool. Miller and Glarborg 1999 mentioned in their study that inclusion of $\mathrm{HNOH}$ chemistry in their model did not have any significant effect

on the performance. Glarborg et al. ${ }^{59}$ and Skreiberg et al. ${ }^{51}$ suggested in their studies that the 
$\mathrm{HNOH}$ route can be an alternative path to the amine pool $\left(\mathrm{HNO} \rightarrow \mathrm{HNOH} \rightarrow \mathrm{NH}_{2}\right)$. However, both authors reached the same conclusion that the contribution of $\mathrm{HNOH}$ reactions to $\mathrm{NO}$ reduction is limited by the rate of formation of $\mathrm{HNOH}$ via $(\mathrm{HNO}+\mathrm{H}+\mathrm{M} \leftrightharpoons \mathrm{HNOH}+\mathrm{M})$. In our present work the complete HNOH sub-mechanism is adopted from the model of Skreiberg et al. ${ }^{51}$.

\section{HONO/HNO 2 sub-mechanism:}

In the work of Mueller et al. ${ }^{61}$ on the $\mathrm{H}_{2} / \mathrm{O}_{2} / \mathrm{NO}_{\mathrm{x}}$ system $\mathrm{HONO}$ is mainly formed from the $\mathrm{HNO}+\mathrm{NO}_{2} \leftrightharpoons \mathrm{HONO}+\mathrm{NO}$ reaction. At low $\mathrm{NO}$ concentrations, the formed $\mathrm{HONO}$ rapidly dissociates to $\mathrm{NO}$ and $\mathrm{OH}$ via $\mathrm{NO}+\mathrm{OH}(+\mathrm{M}) \leftrightharpoons \mathrm{HONO}(+\mathrm{M})$ and takes part in a chain propagating sequence. With increasing $\mathrm{NO}$ concentration in the system the reaction $\mathrm{HONO}+\mathrm{OH} \leftrightharpoons \mathrm{NO}_{2}+\mathrm{H}_{2} \mathrm{O}$ becomes important and together with reactions $\mathrm{NO}+\mathrm{H}(+\mathrm{M}) \leftrightharpoons \mathrm{HNO}(+\mathrm{M})$ and $\mathrm{HNO}+\mathrm{NO}_{2} \leftrightharpoons \mathrm{HONO}+\mathrm{NO}$ it forms a chain terminating sequence with net result $\mathrm{H}+\mathrm{OH} \leftrightharpoons \mathrm{H}_{2} \mathrm{O}$. In the experimental and modeling work of Glarborg et al. ${ }^{64}$ on the $\mathrm{CO} / \mathrm{NO}_{\mathrm{x}}$ combustion in a flow reactor $\mathrm{HONO}$ is found to be formed via the recombination reaction $\mathrm{NO}+\mathrm{OH}(+\mathrm{M}) \leftrightharpoons \mathrm{HONO}(+\mathrm{M})$ and the formed $\mathrm{HONO}$ reacts mainly with $\mathrm{OH}$ to form $\mathrm{NO}_{2}\left(\mathrm{HONO}+\mathrm{OH} \leftrightharpoons \mathrm{NO}_{2}+\mathrm{H}_{2} \mathrm{O}\right)$ taking part in a chain terminating process. In our present study we find small amounts of $\mathrm{NO}_{2}$ reacting with the $\mathrm{HO}_{2}$ radical forming $\mathrm{HONO}+\mathrm{O}_{2}$. The formed $\mathrm{HONO}$ thermally decomposes to form $\mathrm{NO}+\mathrm{OH}$ producing the reactive $\mathrm{OH}$ radical. Therefore, it is obvious that depending on the various conditions HONO chemistry can inhibit or promote the reactivity of the system. In our present work the HONO sub-scheme is taken from the model of Rasmussen et al. ${ }^{53}$. The additional reactions $\mathrm{HONO}+\mathrm{H} \leftrightharpoons \mathrm{HNO}+\mathrm{OH}$ and $\mathrm{HONO}+\mathrm{H} \leftrightharpoons \mathrm{NO}+\mathrm{H}_{2} \mathrm{O}$ which were not included in ${ }^{53}$ are adopted from Skreiberg et al. ${ }^{51}$. 
$\mathrm{HNO}_{2}$ is a structural isomer of $\mathrm{HONO}$ and in our present study we find $\mathrm{HNO}_{2}$ is mainly formed via the reaction $\mathrm{NO}_{2}+\mathrm{HO}_{2} \leftrightharpoons \mathrm{HNO}_{2}+\mathrm{O}_{2}$ and $\mathrm{NO}_{2}+\mathrm{H}_{2} \leftrightharpoons \mathrm{HNO}_{2}+\mathrm{H}$. Since $\mathrm{HNO}_{2}$ is less stable than

HONO ${ }^{53}$ it readily isomerizes to more the stable HONO. Other reactions that can take part in $\mathrm{HNO}_{2}$ consumption are $\mathrm{HNO}_{2}+\mathrm{O} \leftrightharpoons \mathrm{NO}_{2}+\mathrm{OH}$ and $\mathrm{HNO}_{2}+\mathrm{OH} \leftrightharpoons \mathrm{NO}_{2}+\mathrm{H}_{2} \mathrm{O}$. The rate parameters of these reaction are adopted from Rasmussen et al. ${ }^{53}$ and are based on ab initio calculations on the CBS-QB3 level of theory.

\section{$\mathrm{HONO}_{2}$ sub-mechanism:}

$\mathrm{HONO}_{2}$ formation can happen via two reaction channels: $\mathrm{NO}_{2}+\mathrm{OH}(+\mathrm{M}) \leftrightharpoons \mathrm{HONO}_{2}(+\mathrm{M})$ and $\mathrm{HONO}+\mathrm{NO}_{2} \leftrightharpoons \mathrm{HONO}_{2}+\mathrm{NO}$. Among these, the former route is only important for $\mathrm{HONO}_{2}$ formation. $\mathrm{HONO}_{2}$ consumption proceeds mainly via the reactions with $\mathrm{H}$ and $\mathrm{OH}$ radicals:

$\mathrm{HONO}_{2}+\mathrm{H} \leftrightharpoons \mathrm{H}_{2}+\mathrm{NO}_{3}$

$\mathrm{HONO}_{2}+\mathrm{H} \leftrightharpoons \mathrm{H} 2 \mathrm{O}+\mathrm{NO}_{2}$

$\mathrm{HONO}_{2}+\mathrm{H} \leftrightharpoons \mathrm{OH}+\mathrm{HONO}$

$\mathrm{HONO}_{2}+\mathrm{OH} \leftrightharpoons \mathrm{H}_{2} \mathrm{O}+\mathrm{NO}_{3}$.

The $\mathrm{HONO}_{2}$ scheme and the rate parameters are adopted from Rasmussen et al. ${ }^{53}$.

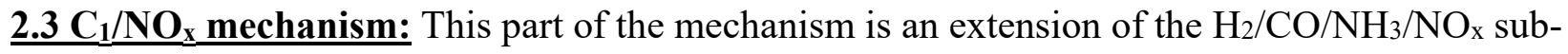
mechanisms. The $\mathrm{H}_{2} / \mathrm{CO}$ submechanism is extended to include $\mathrm{C}_{1}$ chemistry and the $\mathrm{NH}_{3} / \mathrm{NO}_{\mathrm{x}}$ submechanism is extended to include nitrogen chemistry related to carbon species. The target is to include $\mathrm{C}_{1}$ hydrocarbon species as fuel molecules; i.e. methane $\left(\mathrm{CH}_{4}\right)$, methanol $\left(\mathrm{CH}_{3} \mathrm{OH}\right)$ and formaldehyde $\left(\mathrm{CH}_{2} \mathrm{O}\right)$. 
The present model is different from most of the published models in the literature because it is able to predict combustion characteristics of the fuels $\mathrm{H}_{2}, \mathrm{CO}, \mathrm{NH}_{3}$ to $\mathrm{C}_{1}$ together with $\mathrm{NO}_{\mathrm{x}}$ chemistry. This makes the model more robust for in cylinder combustion modelling of conditions which cannot be studied in standard reactor experiments typically used for model development. The complete reaction mechanism is provided in the supporting information.

2.4 Thermochemistry and Transport properties: The thermochemical properties for the species in the $\mathrm{H} / \mathrm{C} / \mathrm{O}$ mechanism are adopted from the Goos et al. thermochemical database ${ }^{85}$. The thermochemical properties of nitrogen species are adopted from Lamoureux et al. ${ }^{16}$ except for those additional species included in this work. The thermochemistry of additional species are adopted from Goos et al. ${ }^{85}$ while $\mathrm{HNO}_{2}$ and $\mathrm{HONO}_{2}$ thermodata (not available from ${ }^{85}$ ) is adopted from Rasmussen et al. ${ }^{53}$. Furthermore the data for NCN are taken from ${ }^{24}$.

The transport properties for the species in the $\mathrm{H} / \mathrm{C} / \mathrm{O}$ mechanism are taken from Seidel et al. ${ }^{25}$. The transport properties of nitrogen species are adopted from Lamoureux et al. ${ }^{16}$ while those of the additional species are taken from Coppens et al. ${ }^{47}$.

\section{Results and Discussion}

The developed $\mathrm{H}_{2} / \mathrm{CO} / \mathrm{C}_{1} / \mathrm{NH}_{3} / \mathrm{NO}_{\mathrm{x}}$ kinetic model has been validated against a large set of published experimental data. The validation targets include laminar flame speeds, ignition delay times, speciation in burner stabilized premixed flames, speciation in PFR and JSR. Several numerical and experimental investigations on nitrogen chemistry have been reported in the last decades. However, there are only very few investigations on $\mathrm{H}_{2} / \mathrm{NH}_{3} / \mathrm{NO}_{\mathrm{x}}$ and $\mathrm{C}_{1} / \mathrm{NO}_{\mathrm{x}}$ chemistry together. This is the focus of this study. The study also addresses the importance of speciation 
studies in burner stabilized flames. In all plots shown below the lines represent the simulation results using our present model and symbols represent the experimental data from literature unless stated differently. The modeling results are shown for experiments using nitrogen $\left(\mathrm{NH}_{3}, \mathrm{NO}, \mathrm{N}_{2} \mathrm{O}\right.$, $\mathrm{NO}_{2}$ ) containing fuels. All simulations were performed using the LOGEsoft 1.08.00 ${ }^{86}$ package.

\section{1 $\mathrm{H}_{2} / \mathrm{CO} / \mathrm{NH}_{3} / \mathrm{NO}_{\mathrm{x}}$ model validation}

In this section we will validate our proposed model against a wide range of experimental data published in the literature and briefly comment on the model performance. Table 2 summarizes the experimental studies which we used for model development and validation.

Table 2: Experimental targets used for $\mathrm{H}_{2} / \mathrm{CO} / \mathrm{NH}_{3} / \mathrm{NO}_{\mathrm{x}}$ model development and validation

\begin{tabular}{|c|c|c|c|}
\hline Experimental devices & $\begin{array}{l}\text { Measured } \\
\text { Properties }\end{array}$ & Experimental conditions & References \\
\hline Cylindrical flow tube ${ }^{(\text {Fig.1) }}$ & $\begin{array}{l}\text { Laminar flame } \\
\text { speed } \\
\text { (1 data set) }\end{array}$ & $\begin{array}{l}1.0 \mathrm{~atm}, 293 \mathrm{~K}, \phi=0.8-1.25 \text { for } \\
\mathrm{NH}_{3} / \text { air mixture }\end{array}$ & Zakaznov et al. ${ }^{87}$ \\
\hline $\begin{array}{l}\text { Constant volume } \\
\text { Combustion vessel }^{(\text {Fig.1) }}\end{array}$ & $\begin{array}{l}\text { Laminar flame } \\
\text { speed } \\
\text { (1 data set) }\end{array}$ & $\begin{array}{l}101 \mathrm{kPa}, 295 \mathrm{~K}, \phi=0.72-1.12 \text { for } \\
\mathrm{NH}_{3} / \text { air mixture }\end{array}$ & Pfahl et al. ${ }^{88}$ \\
\hline $\begin{array}{l}\text { Constant volume } \\
\text { combustion vessel }^{(\text {Fig.1) }}\end{array}$ & $\begin{array}{l}\text { Laminar flame } \\
\text { speed }\end{array}$ & $\begin{array}{l}1.0 \text { atm, } 298 \mathrm{~K}, \phi=0.8-1.78 \text { for } \\
\mathrm{NH}_{3} / \text { air mixture }\end{array}$ & Ronney ${ }^{89}$ \\
\hline $\begin{array}{l}\text { Constant volume } \\
\text { combustion vessel }^{(\text {Fig.1) }}\end{array}$ & $\begin{array}{l}\text { Laminar flame } \\
\text { speed } \\
\text { (1 data set) }\end{array}$ & $\begin{array}{l}1.0 \mathrm{~atm}, 295 \mathrm{~K}, \phi=0.9-1.3 \text { for } \\
\mathrm{NH}_{3} / \text { air mixture }\end{array}$ & Jabbour \& Clodic ${ }^{90}$ \\
\hline $\begin{array}{l}\text { Constant volume } \\
\text { combustion vessel }^{(\text {Fig.1) }}\end{array}$ & $\begin{array}{l}\text { Laminar flame } \\
\text { speed } \\
\text { (1 data set) }\end{array}$ & $\begin{array}{l}1.05 \mathrm{~atm}, 298 \mathrm{~K}, \phi=0.9-1.2 \text { for } \\
\mathrm{NH}_{3} / \text { air mixture }\end{array}$ & Takizawa et al..$^{91}$ \\
\hline $\begin{array}{l}\text { Constant volume } \\
\text { combustion vessel }^{\text {(Fig.1, }} \\
\text { Fig.S2) }\end{array}$ & $\begin{array}{l}\text { Laminar flame } \\
\text { speed } \\
\text { (3 data set) }\end{array}$ & $\begin{array}{l}\text { 1.0-5.0 bar, } 298 \mathrm{~K}, \phi=0.7-1.3 \text { for } \\
\mathrm{NH}_{3} / \text { air mixture }\end{array}$ & Hayakawa et al. ${ }^{18}$ \\
\hline $\begin{array}{l}\text { Constant volume } \\
\text { combustion vessel }^{(\text {Fig.S1) }}\end{array}$ & $\begin{array}{l}\text { Laminar flame } \\
\text { speed } \\
\text { (1 data set) }\end{array}$ & $\begin{array}{l}1.0 \mathrm{~atm}, 298 \mathrm{~K}, \phi=1.0 \text { for } \\
\mathrm{NH}_{3} / \mathrm{H}_{2} / \text { air mixture, } \mathrm{H}_{2}=0.1-0.5\end{array}$ & Lee et al. ${ }^{92}$ \\
\hline $\begin{array}{l}\text { Constant volume } \\
\text { combustion vessel }^{(\mathrm{Fig} . \mathrm{S} 1)}\end{array}$ & $\begin{array}{l}\text { Laminar flame } \\
\text { speed (1 data set) }\end{array}$ & $\begin{array}{l}1.0 \mathrm{~atm}, 298 \mathrm{~K}, \phi=1.0 \text { for } \\
\mathrm{NH}_{3} / \mathrm{H}_{2} / \text { air mixture, } \mathrm{H}_{2}=0.35- \\
0.55\end{array}$ & Li et al. ${ }^{20}$ \\
\hline $\begin{array}{l}\text { Constant volume } \\
\text { combustion vessel }^{\text {(Fig.S1) }}\end{array}$ & $\begin{array}{l}\text { Laminar flame } \\
\text { speed (1 data set) }\end{array}$ & $\begin{array}{l}101 \mathrm{kPa}, 298 \mathrm{~K}, \phi=0.1-4.0 \text { for } \\
\mathrm{NH}_{3} / \mathrm{NO} \text { mixture }\end{array}$ & Checkel et al. ${ }^{93}$ \\
\hline $\begin{array}{l}\text { McKenna flat flame } \\
\text { burner }^{\text {(Fig.S2) }}\end{array}$ & $\begin{array}{l}\text { Laminar flame } \\
\text { speed (1 data set) }\end{array}$ & $\begin{array}{l}0.8 \mathrm{~atm}, 298 \mathrm{~K}, \phi=0.8-2.2 \text { for } \\
\mathrm{H}_{2} / \mathrm{N}_{2} \mathrm{O} / \mathrm{N}_{2} \text { mixture }\end{array}$ & Powell et al. ${ }^{72}$ \\
\hline
\end{tabular}




\begin{tabular}{|c|c|c|c|}
\hline Shock tube ${ }^{(\text {Fig.2,Fig.S3) }}$ & $\begin{array}{l}\text { Ignition delay } \\
\text { times ( } 12 \text { data sets) }\end{array}$ & $\begin{array}{l}1.4-30.0 \text { atm, } 1560-2455 \mathrm{~K}, \phi= \\
0.5-2.0 \text { for } \mathrm{NH}_{3} / \mathrm{O}_{2} / \mathrm{Ar} \\
\text { mixtures }\end{array}$ & Mathieu and Petersen ${ }^{17}$ \\
\hline Shock tube ${ }^{\text {(Fig.3,Fig.S4) }}$ & $\begin{array}{l}\text { Ignition delay } \\
\text { times (12 data sets) }\end{array}$ & $\begin{array}{l}1.6-32.0 \text { atm, } 940-1675 \mathrm{~K}, \phi=0.5 \\
\text { for } \mathrm{H}_{2} / \mathrm{O}_{2} / \mathrm{N}_{2} \mathrm{O} / \mathrm{Ar} \\
\text { mixtures }\end{array}$ & Mathieu et al. ${ }^{77}$ \\
\hline Shock tube (Fig.3,Fig.S6) & $\begin{array}{l}\text { Ignition delay } \\
\text { times ( } 12 \text { data sets) }\end{array}$ & $\begin{array}{l}1.5-30.0 \text { atm, } 1038-1744 \mathrm{~K}, \phi= \\
0.3-1.0 \text { for } \mathrm{H}_{2} / \mathrm{O}_{2} / \mathrm{NO}_{2} / \mathrm{Ar} \\
\text { mixtures }\end{array}$ & Mathieu et al. ${ }^{63}$ \\
\hline Shock tube ${ }^{(\text {Fig.S5) }}$ & $\begin{array}{l}\text { Ignition delay } \\
\text { times ( } 3 \text { data sets) }\end{array}$ & $\begin{array}{l}2.0 \text { atm, } 1400-2000 \mathrm{~K}, \phi=0.5-2.0 \\
\mathrm{H}_{2} / \mathrm{N}_{2} \mathrm{O} / \text { Ar mixtures }\end{array}$ & Hidaka et al. $^{56}$ \\
\hline Shock tube ${ }^{\text {(Fig.S7) }}$ & $\begin{array}{l}\text { Ignition delay } \\
\text { times ( } 2 \text { data sets) }\end{array}$ & $\begin{array}{l}\text { 1.4-10.4 atm, 1654-2221 K for } \\
\mathrm{H}_{2} / \mathrm{CO} / \mathrm{N}_{2} \mathrm{O} / \text { Ar mixture }\end{array}$ & Kopp et al. ${ }^{71}$ \\
\hline $\begin{array}{l}\text { Jet stirred reactor (Fig.4, Fig.5, } \\
\text { Fig.S8-Fig.S12) }\end{array}$ & $\begin{array}{l}\text { Species profiles } \\
\text { ( } 78 \text { data sets) }\end{array}$ & $\begin{array}{l}1.0-10.0 \text { atm, } 700-1150 \mathrm{~K}, \phi= \\
0.1-2.5 \text { for } \mathrm{H}_{2} / \mathrm{O}_{2} / \mathrm{NO}_{\mathrm{x}} / \mathrm{N}_{2} \\
\text { mixtures }\end{array}$ & Dayma \& Dagaut ${ }^{62}$ \\
\hline $\begin{array}{l}\text { Jet stirred reactor } \\
\text { (Fig.S13,Fig.S14) }\end{array}$ & $\begin{array}{l}\text { Species profiles } \\
\text { (9 data sets) }\end{array}$ & $\begin{array}{l}1.0 \mathrm{~atm}, 800-1400 \mathrm{~K}, \phi=0.1-2.0 \\
\text { for } \mathrm{H}_{2} / \mathrm{CO} / \mathrm{O}_{2} / \mathrm{NO}_{\mathrm{x}} / \mathrm{N}_{2} \\
\text { mixtures }\end{array}$ & Dagaut et al. ${ }^{94}$ \\
\hline Flow reactor ${ }^{\text {(Fig.6) }}$ & $\begin{array}{l}\text { Species profiles } \\
(3 \text { data sets })\end{array}$ & $\begin{array}{l}10.0 \text { atm, } 802 \mathrm{~K}, \mathrm{H}_{2} / \mathrm{O}_{2} / \mathrm{NO} \\
\text { mixtures }\end{array}$ & Mueller et al. $^{61}$ \\
\hline Flow reactor ${ }^{(\text {Fig.S15) }}$ & $\begin{array}{l}\text { Species profiles } \\
\text { (4 data sets) }\end{array}$ & $\begin{array}{l}3.0 \text { atm, } 995 \mathrm{~K}, \mathrm{H}_{2} / \mathrm{N}_{2} \mathrm{O} / \mathrm{NH}_{3} / \mathrm{N}_{2} \\
\text { mixtures }\end{array}$ & Allen et al. ${ }^{45}$ \\
\hline $\begin{array}{l}\text { Flow reactor }{ }^{\text {(Fig.7,Fig.S16- }} \\
\text { Fig.S18) }\end{array}$ & $\begin{array}{l}\text { Species profiles } \\
\text { ( } 22 \text { data sets) }\end{array}$ & $\begin{array}{l}1.05 \mathrm{~atm}, 800-1400 \mathrm{~K} \\
\mathrm{CO} / \mathrm{O}_{2} / \mathrm{NO} / \mathrm{NO}_{2} / \mathrm{H}_{2} \mathrm{O} / \mathrm{N}_{2} \\
\text { mixtures }\end{array}$ & Glarborg et al. ${ }^{64}$ \\
\hline Buner stabilized flame ${ }^{\text {(Fig.8) }}$ & $\begin{array}{l}\text { Species profiles } \\
\text { ( } 7 \text { data sets })\end{array}$ & $\begin{array}{l}4.7 \mathrm{kPa}, 298 \mathrm{~K}, \phi=1.91 \\
\mathrm{H}_{2} / \mathrm{O}_{2} / \mathrm{NH}_{3} / \text { Ar mixture }\end{array}$ & Vandooren ${ }^{95}$ \\
\hline $\begin{array}{l}\text { Buner stabilized } \\
\text { flame }^{(\text {Fig.S19,Fig.S20) }}\end{array}$ & $\begin{array}{l}\text { Species profiles } \\
\text { (4 data sets) }\end{array}$ & $\begin{array}{l}4.6 \mathrm{kPa}, 298 \mathrm{~K}, \phi=0.12-1.0, \\
\mathrm{NH}_{3} / \mathrm{H}_{2} / \mathrm{O}_{2} / \mathrm{Ar} \text { mixture }\end{array}$ & Bian \& Vandooren ${ }^{96}$ \\
\hline $\begin{array}{l}\text { Buner stabilized } \\
\text { flame }^{(\text {Fig.S19,Fig.S20) }}\end{array}$ & $\begin{array}{l}\text { Species profiles } \\
\text { (4 data sets) }\end{array}$ & $\begin{array}{l}4.6 \mathrm{kPa}, 298 \mathrm{~K}, \phi=0.12-1.0, \\
\mathrm{NH}_{3} / \mathrm{H}_{2} / \mathrm{NO} / \mathrm{O}_{2} / \text { Ar mixture }\end{array}$ & Bian \& Vandooren ${ }^{96}$ \\
\hline $\begin{array}{l}\text { Buner stabilized } \\
\text { flame }^{\text {(Fig.S21) }}\end{array}$ & $\begin{array}{l}\text { Species profiles } \\
(8 \text { data sets })\end{array}$ & $\begin{array}{l}7.2 \mathrm{kPa}, 298 \mathrm{~K}, \phi=1.46 \\
\mathrm{NH}_{3} / \mathrm{NO} / \text { Ar mixture }\end{array}$ & Vandooren et al. ${ }^{97}$ \\
\hline $\begin{array}{l}\text { Buner stabilized } \\
\text { flame }^{(\text {Fig.S22) }}\end{array}$ & $\begin{array}{l}\text { Species profiles } \\
(9 \text { data sets })\end{array}$ & $\begin{array}{l}5.0 \mathrm{kPa}, 298 \mathrm{~K}, \phi=1.0, \\
\mathrm{NH}_{3} / \mathrm{H}_{2} / \mathrm{O}_{2} / \text { Ar mixture }\end{array}$ & Duynslaegher et al. ${ }^{98}$ \\
\hline $\begin{array}{l}\text { Buner stabilized } \\
\text { flame }^{\text {(Fig.S23) }}\end{array}$ & $\begin{array}{l}\text { Species profiles } \\
(5 \text { data sets })\end{array}$ & $\begin{array}{l}4.0 \mathrm{kPa}, 300 \mathrm{~K}, \phi=1.08 \\
\mathrm{H}_{2} / \mathrm{N}_{2} \mathrm{O} / \text { Ar mixture }\end{array}$ & Sausa et al. ${ }^{73}$ \\
\hline $\begin{array}{l}\text { Buner stabilized } \\
\text { flame }^{(\text {Fig.9,Fig.S24,Fig.S25) }}\end{array}$ & $\begin{array}{l}\text { Species profiles } \\
\text { (18 data sets) }\end{array}$ & $\begin{array}{l}6.66 \mathrm{kPa}, 298 \mathrm{~K}, \phi=1.0-1.5, \\
\mathrm{CO} / \mathrm{N}_{2} \mathrm{O} / \text { Ar mixture }\end{array}$ & Dindi et al. ${ }^{74}$ \\
\hline
\end{tabular}

$\mathrm{S}=$ in Supporting Information

Laminar flame speed: Predicted $\mathrm{NH}_{3}$ /air laminar burning velocities are shown in Figure 1 in comparison to the available experimental data. Most experimental data resulted from closed vessel experiments. The 1978 measurements by Zakaznov ${ }^{87}$ were performed by a cylindrical flow tube. Among the measured laminar burning velocities there is a good agreement for fuel lean and 
stoichiometric conditions. For fuel rich conditions a significant discrepancy is noticed. Our model captures the experimental trends from lean to stoichiometric condition very well. For lean conditions the best agreement is found with data by Pfahl $2000{ }^{88}$. For fuel rich conditions the model agrees with the older measurements from Ronney $1988^{89}$. Newer Experiments by Takizawa $20088^{91}$ and Hayakawa $2015^{18}$ follow the trend of Zakaznov ${ }^{87}$. Data by Jabbour $2004{ }^{90}$ are closer to the data by Rooney 1988. Recently, Nakamura et al. ${ }^{99}$ performed an experimental and kinetic modeling study of weak ammonia-air flames in a micro flow reactor. In addition they compared laminar flame speeds of ammonia-air flames available from the literature with predictions of five different mechanisms including their own model. They ${ }^{99}$ showed that none of the mechanisms was able to predict the experimental laminar flame speeds on the lean and the fuel rich side at the same time. Testing the impact of the thermodynamic data for $\mathrm{NH}_{3}, \mathrm{NH}_{2}$ and $\mathrm{NH}$ from Bugler et al. ${ }^{100}$ we can rule out that the problem is related to thermodynamic properties. However, we are unable to explain where these discrepancies come from. Therefore this problem remains and should be addressed by the combustion community in the future from both the experimental and the modelling side. Flow analyses shows that $\mathrm{NH}_{3}$ undergoes hydrogen abstraction by $\mathrm{O}, \mathrm{H}$ and $\mathrm{OH}$ radicals and decomposes to the Amidogen radical $\left(\mathrm{NH}_{2}\right)$, which further decomposes to the Imidogen radical $(\mathrm{NH})$. Both are very reactive species and their reactions with $\mathrm{H}, \mathrm{O}, \mathrm{OH}$, and $\mathrm{NO}$ control the overall reactivity of the system. The thermal decomposition of $\mathrm{NH}_{3}$ which forms $\mathrm{NH}_{2}$ and $\mathrm{H}$ is also sensitive on the laminar flame speed. We also demonstrate the importance of the $\mathrm{N}_{2} \mathrm{H}_{\mathrm{x}}$ chemistry in Figure 1. Without this chemical mechanism we predict significant lower laminar flame speeds for all fuel-air equivalences radius. 

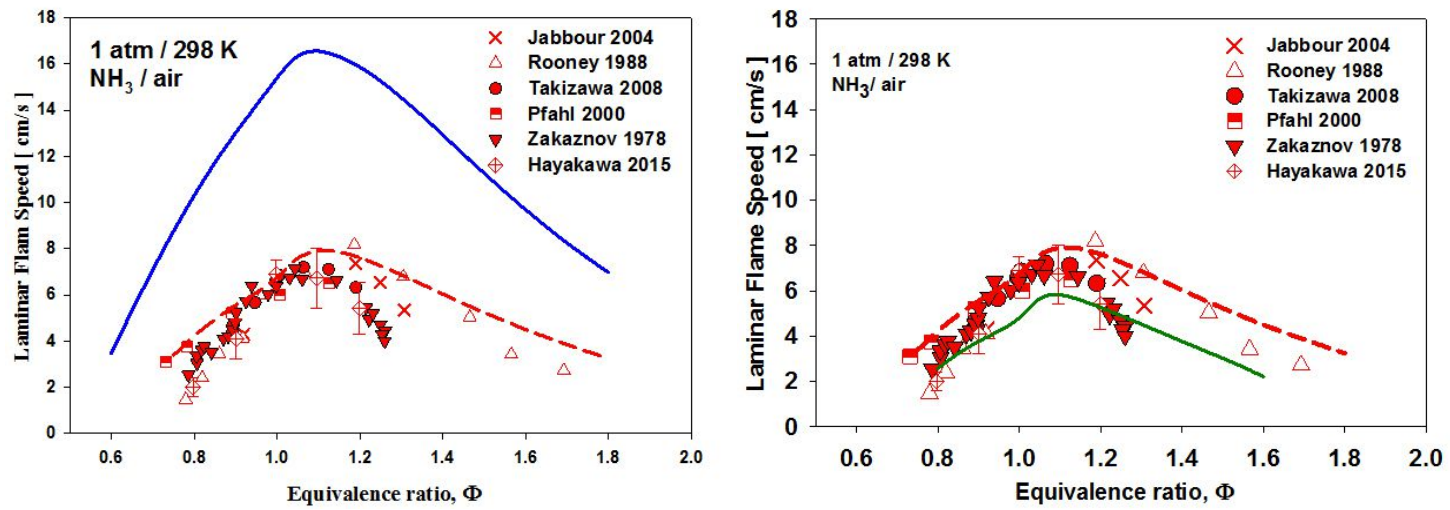

Figure 1: Laminar flame speed for $\mathrm{NH}_{3} /$ air blends at 1 atm and 298K. Symbols: experiments from 18,87-91. Left figure: dashed line; this model prediction, solid line: Lamoureux et al. ${ }^{16}$ model prediction. Right figure: dashed line, this model prediction; solid line, model prediction without $\mathrm{N}_{2} \mathrm{H}_{x}$ scheme.

Ignition delay times: Ignition delay time data from shock tube experiments published in the literature cover pressure ranges which are relevant for practical combustion systems. The ignition delay times of $\mathrm{NH}_{3} / \mathrm{O}_{2}$ blends with high dilution of $\mathrm{Ar}$ were reported by Mathieu et al. ${ }^{17}$ in the pressure range of 1.4-30.0 atm for the fuel-air equivalence ratio range, $\phi=0.5-2.0$. As can be seen from Figure 2 the present model captures the experimental trends in temperature for all pressures and equivalence ratios. It can also be observed from Figure 2 that with increasing pressure the ignition delay time of ammonia monotonously decreases. 


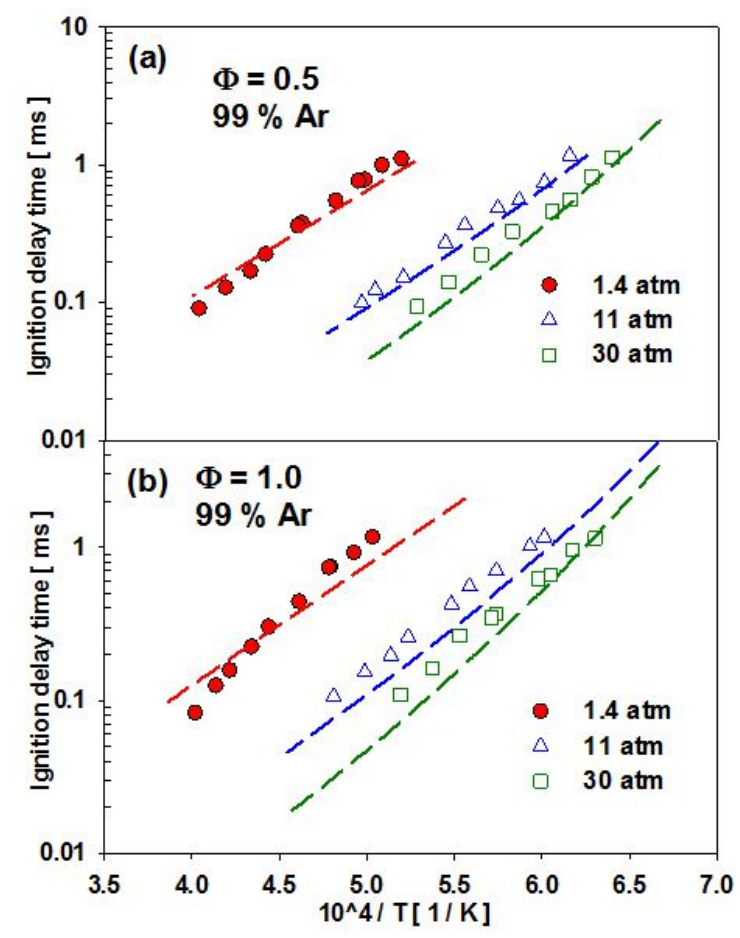

Figure 2: Ignition delay times from shock tube experiments in comparison to model predictions for $\mathrm{NH}_{3} / \mathrm{O}_{2} / \mathrm{Ar}$ blends. Symbols: experiments from ${ }^{17}$, dashed lines: model predictions.

To further validate the $\mathrm{H} / \mathrm{N} / \mathrm{O}$ chemistry, experiments investigating the sensitivity of the addition of $\mathrm{NO}_{2}$ and $\mathrm{N}_{2} \mathrm{O}$ to $\mathrm{H}_{2} / \mathrm{O}_{2} / \mathrm{Ar}$ blends on ignition delay times are shown in Figure 3. The comparison shows that 1600 ppm of $\mathrm{N}_{2} \mathrm{O}$ have almost no sensitivity on the $\mathrm{H}_{2}$ chemistry (3a with $3 b$ ), while $100 \mathrm{ppm}$ of $\mathrm{NO}_{2}$ (3a with $3 \mathrm{~b}$ ) are enough to change the pressure dependence of $\mathrm{H}_{2}$ autoignition. We note that in simulations without $\mathrm{N}_{2} \mathrm{O}$ the ignition is slightly delayed at high temperatures resulting in deviations from the experiment, especially for the lowest pressure. The experiments with $\mathrm{NO}_{2}$ still show a significant influence of the chain breaking reaction $\mathrm{H}+\mathrm{O}_{2}+\mathrm{M} \leftrightharpoons \mathrm{HO}_{2}+\mathrm{M}$ on the $\mathrm{H}_{2}$ ignition delay times, resulting in the crossing lines for the ignition delays, which are moved at higher pressure to higher temperature. In the supporting information the low sensitivity of $\mathrm{N}_{2} \mathrm{O}$ is further demonstrated in figure $\mathrm{S} 4 . \mathrm{NO}_{2}$ can suppress this effect through direct reactions with $\mathrm{HO}_{2}$ through reaction $\mathrm{NO}_{2}+\mathrm{HO}_{2} \leftrightharpoons \mathrm{HONO}+\mathrm{O}_{2}$ resulting in a chain propagation instead of a chain 
breaking effect through the thermal decomposition of $\mathrm{HONO}$ via $\mathrm{HONO} \leftrightharpoons \mathrm{NO}+\mathrm{OH}$. This reaction path only becomes relevant if high enough concentrations of $\mathrm{HO}_{2}$ are available in the oxidizing gas mixture. The kinetic model predicts this sensitivity in agreement to the experiments. A comparable reaction path does not exist for $\mathrm{N}_{2} \mathrm{O}$, which can explain the week sensitivity of $\mathrm{N}_{2} \mathrm{O}$.
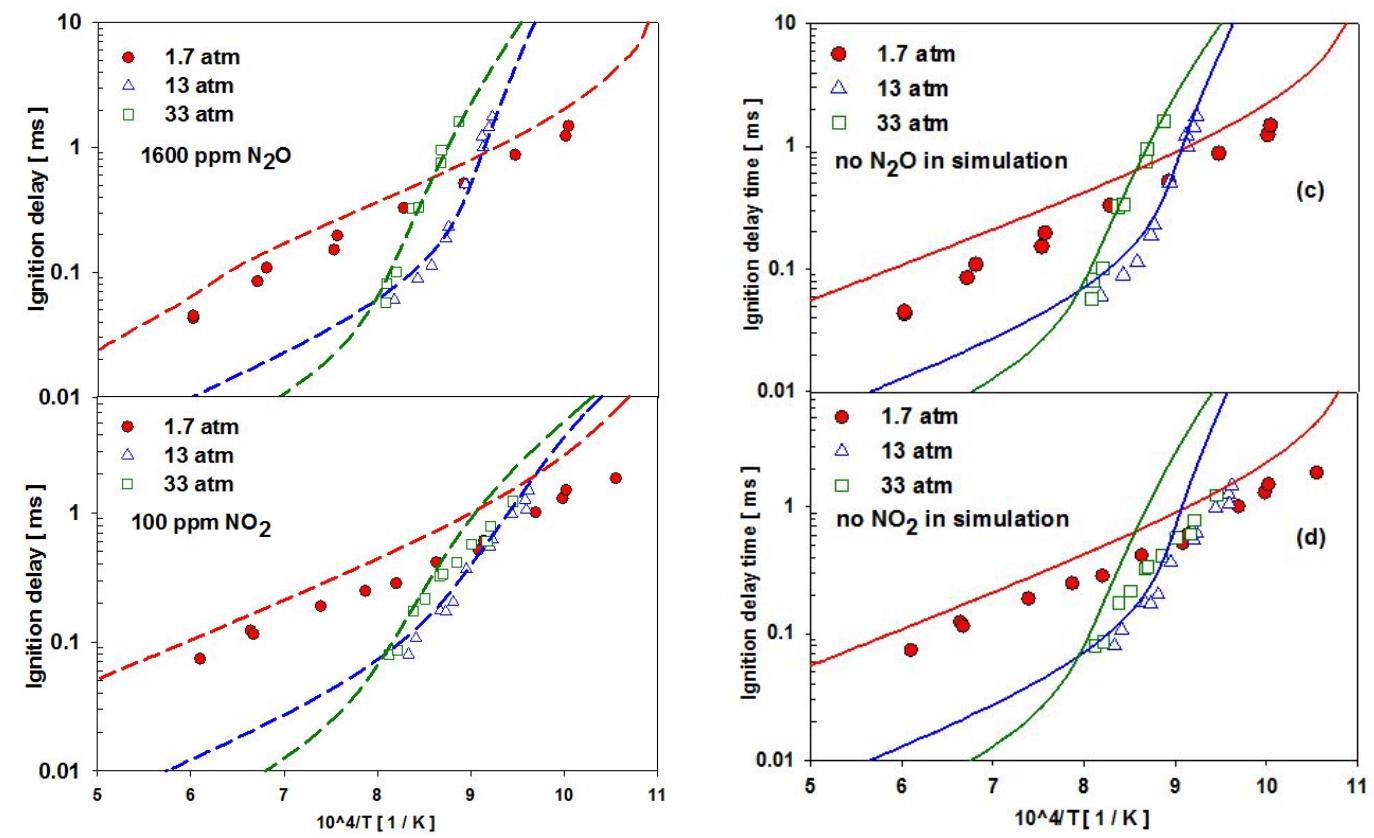

Figure 3: Ignition delay times from shock tube experiments of $\mathrm{H}_{2} / \mathrm{O}_{2} / \mathrm{N}_{2} \mathrm{O} / \mathrm{Ar}$ and $\mathrm{H}_{2} / \mathrm{O}_{2} / \mathrm{NO}_{2} / \mathrm{Ar}$ blends. Left: (a), $\mathrm{H}_{2}(0.01) / \mathrm{O}_{2}(0.01) / \mathrm{N}_{2} \mathrm{O}(0.0016)$; (b), $\mathrm{H}_{2}(0.01) / \mathrm{O}_{2}(0.01) / \mathrm{NO}_{2}(0.0001)$, symbols experiments from ${ }^{63,77}$, dashed lines: model prediction. Right: (c) and (d) symbols same as in figure (a) and (b) respectively, solid lines model prediction without $\mathrm{N}_{2} \mathrm{O}$ and $\mathrm{NO}_{2}$ doping.

In addition a sensitivity analysis towards ignition delay time was performed at $1160 \mathrm{~K}$ for two different pressure: $1.7 \mathrm{~atm}$ and $33 \mathrm{~atm}$. The mixture composition for both pressures is the same (as mentioned in Figure 3(b)) including a small amount of $\mathrm{NO}_{2}$. Figure 4 shows the most sensitive reactions for each pressure. It can be observed that the sensitivity varies strongly with pressure. The most important chain propagating reaction for both pressures is the reaction $\mathrm{O}_{2}+\mathrm{H} \leftrightharpoons \mathrm{OH}+\mathrm{O}$ 
while at $33.0 \mathrm{~atm}$ its sensitivity is 3 times higher compared to that at $1.7 \mathrm{~atm}$. The most sensitive reaction to prolong ignition delay time (negative sensitivity) is $\mathrm{H}+\mathrm{O}_{2}(+\mathrm{M}) \leftrightharpoons \mathrm{HO}_{2}(+\mathrm{M})$ at $33.0 \mathrm{~atm}$. This reaction is not found to be sensitive at $1.7 \mathrm{~atm}$. The most sensitive $\mathrm{NO}_{\mathrm{x}}$ chemistry reaction is $\mathrm{NO}+\mathrm{HO}_{2} \leftrightharpoons \mathrm{NO}_{2}+\mathrm{OH}$ at 33.0 atm. In general all reactions involving $\mathrm{NO}_{2}$ are found to have increasing sensitivities with increasing pressure, which is in agreement with the observation made in Figure 3 (b) and 3 (d). The most notable observation from this analysis is that the sensitivity direction of the reaction $\mathrm{NO}_{2}+\mathrm{H} \leftrightharpoons \mathrm{NO}+\mathrm{OH}$ changes from negative (prolonging ignition delay time) at $1.7 \mathrm{~atm}$ to positive (shortening ignition delay time) at $33.0 \mathrm{~atm}$. Reactions involving $\mathrm{HO}_{2}$ are generally found to be more sensitive at high pressure which can be explained by the increasing importance of the reaction $\mathrm{H}+\mathrm{O}_{2}(+\mathrm{M}) \leftrightharpoons \mathrm{HO}_{2}(+\mathrm{M})$ forming $\mathrm{HO}_{2}$. 


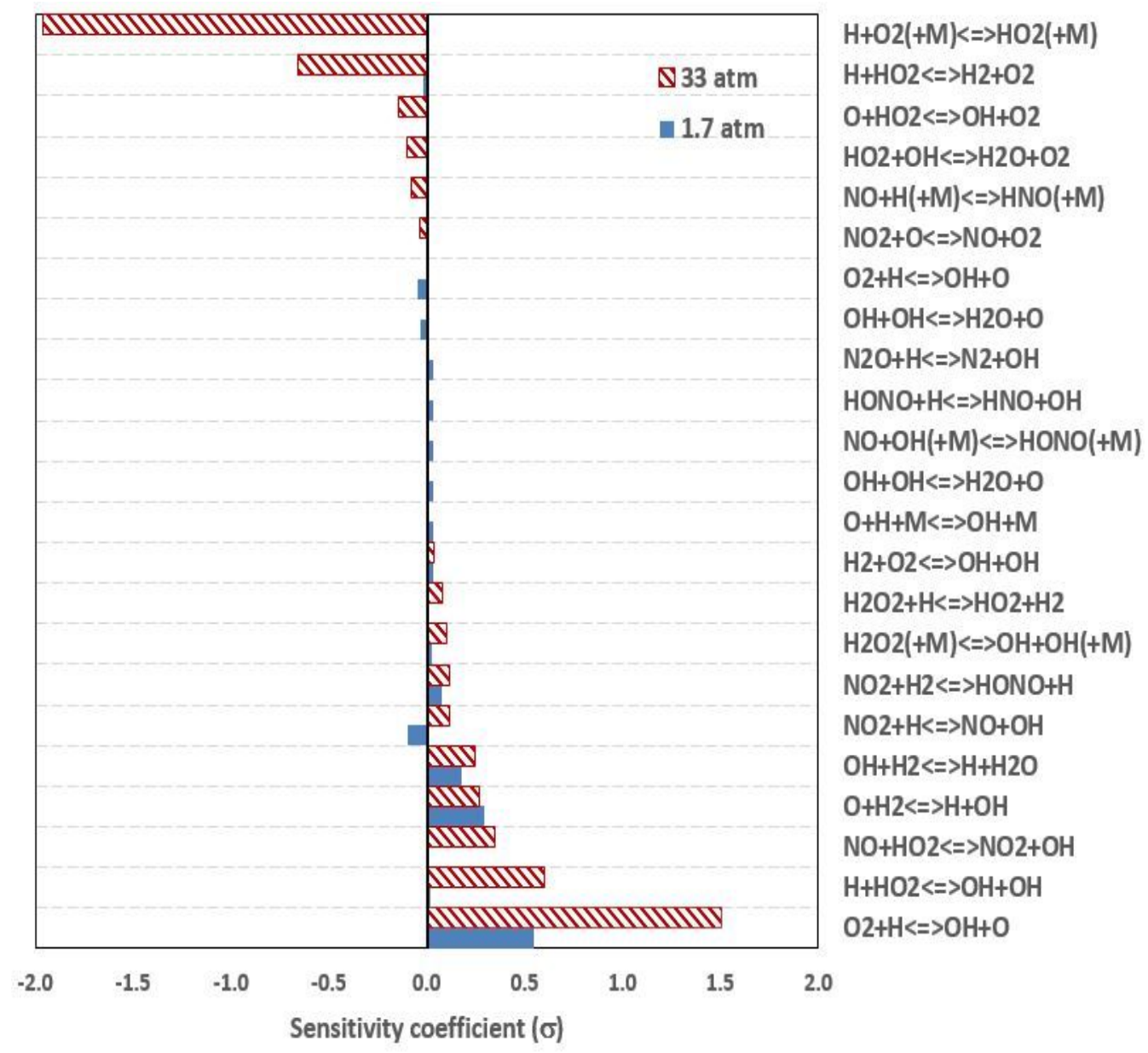

Figure 4: Ignition delay sensitivity coefficient $(\sigma)$ for $\mathrm{H}_{2}(0.01) / \mathrm{O}_{2}(0.01) / \mathrm{NO}_{2}(0.0001) / \mathrm{Ar}$ at 1160 $\mathrm{K}, 33.0 \mathrm{~atm}$ and $1.7 \mathrm{~atm}$.

Speciation in JSR and PFR: To further investigate the sensitivity of $\mathrm{NO}_{\mathrm{x}}$ on the hydrogen chemistry we simulated experiments published in the literature dedicated to $\mathrm{H}_{2} / \mathrm{O}_{2} / \mathrm{N}_{2} / \mathrm{NO}_{x}$, $\mathrm{H}_{2} / \mathrm{CO} / \mathrm{O}_{2} / \mathrm{N}_{2} / \mathrm{NO}_{\mathrm{x}}$ and $\mathrm{CO} / \mathrm{O}_{2} / \mathrm{H}_{2} \mathrm{O} / \mathrm{N}_{2} / \mathrm{NO}_{\mathrm{x}}$ blends in a JSR and PFR. In Figure $5 \mathrm{H}_{2} / \mathrm{O}_{2} / \mathrm{N}_{2}$ blends are doped with $220 \mathrm{ppm}$ of $\mathrm{NO}$ at $10 \mathrm{~atm}$ for a residence time of $1.0 \mathrm{~s}$. NO is consumed and $\mathrm{NO}_{2}$ is formed in the temperature range of $750-1100 \mathrm{~K}$. The conversion of $\mathrm{NO}$ to $\mathrm{NO}_{2}$ is explained by the chain propagation reaction $\mathrm{NO}+\mathrm{HO}_{2} \leftrightharpoons \mathrm{NO}_{2}+\mathrm{OH}$, which is accelerating the $\mathrm{H}_{2}$ chemistry. As can be seen the highest $\mathrm{NO}_{2}$ concentration occurs at $800 \mathrm{~K}$. At higher temperature $\mathrm{H} 2$ oxidation 


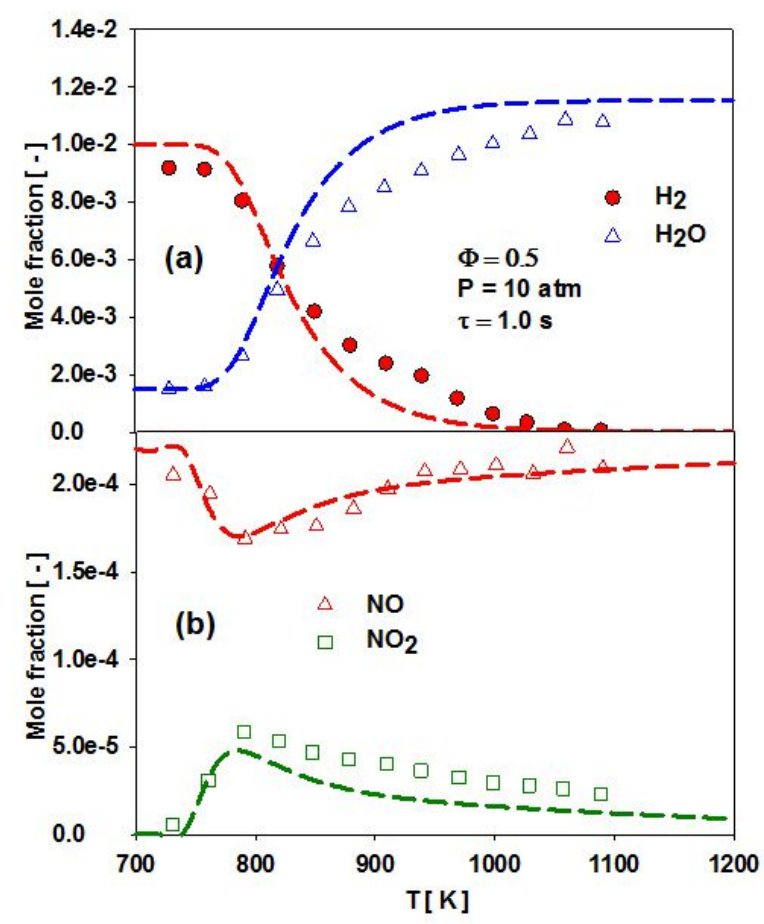

Figure 5: Species profile comparison between measurements and model prediction for $\mathrm{H}_{2}(0.01) / \mathrm{O}_{2}(0.01) / \mathrm{NO}(220 \mathrm{ppm}) / \mathrm{N}_{2}$ oxidation in a JSR at $10 \mathrm{~atm}$, residence time $(\tau)=1.0 \mathrm{~s}$. Symbols: experiments from ${ }^{62}$, dashed lines: model prediction.

continues, and $\mathrm{NO}_{2}$ is reduced to $\mathrm{NO}$ via reaction $\mathrm{NO}_{2}+\mathrm{H} \leftrightharpoons \mathrm{NO}+\mathrm{OH}$. In the $\mathrm{H}_{2} / \mathrm{O}_{2}$ system doped with $\mathrm{NO}_{2}$ (see Figure 6) in the same temperature range as in Figure 5 we do not observe any NO conversion to $\mathrm{NO}_{2}$. In this case (Figure 6) almost all of the $\mathrm{NO}_{2}$ is converted to $\mathrm{NO}$ via the reaction $\mathrm{NO}_{2}+\mathrm{H} \leftrightharpoons \mathrm{NO}+\mathrm{OH}$ and to a lesser extent via $\mathrm{NO}_{2}+\mathrm{O} \leftrightharpoons \mathrm{NO}+\mathrm{O}_{2}$. It can be observed that around $1000 \mathrm{~K}$ where almost all the $\mathrm{NO}_{2}$ is consumed, the peak concentration of $\mathrm{NO}$ is also reached. The doping of the $\mathrm{H}_{2} / \mathrm{O}_{2} / \mathrm{N}_{2}$ blend with $\mathrm{NO}_{2}$ results in a delayed oxidation of the blend. This is explained by the backward reaction $\mathrm{NO}+\mathrm{HO}_{2} \leftrightharpoons \mathrm{NO}_{2}+\mathrm{OH}$, which now consumes reactive $\mathrm{OH}$ to form less reactive $\mathrm{HO}_{2}$. 


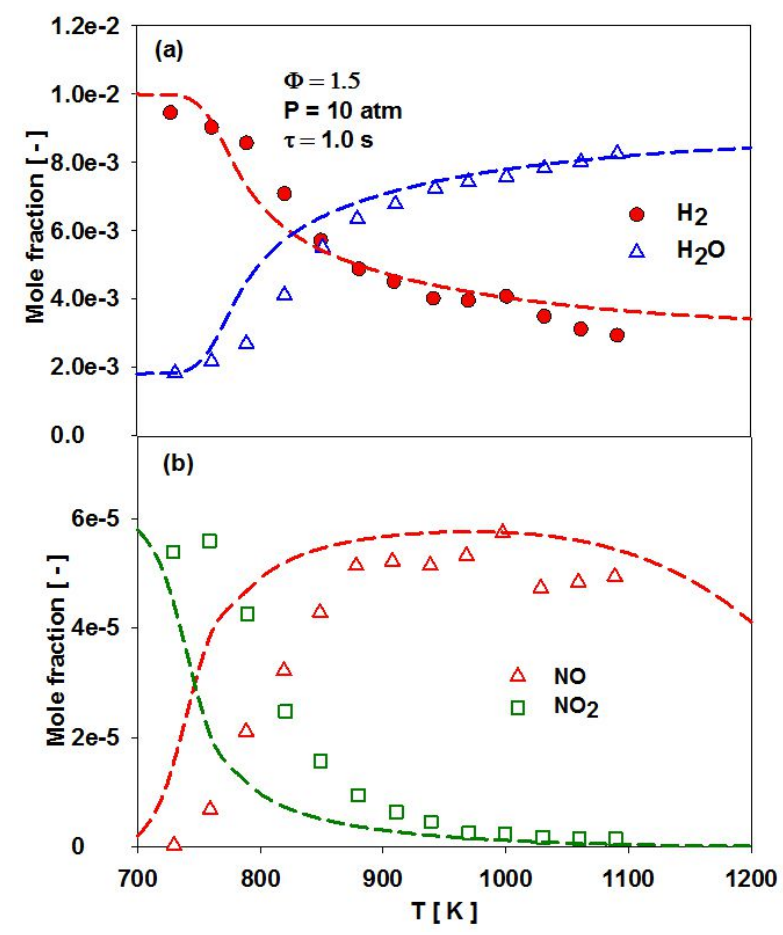

Figure 6: $\mathrm{H}_{2}(0.01) / \mathrm{O}_{2}(0.00333) / \mathrm{NO}_{2}(60 \mathrm{ppm}) / \mathrm{N}_{2}$ oxidation in JSR at 10 atm, residence time, $\tau$ $=1.0 \mathrm{~s}$ and in temperature range $700-1100 \mathrm{~K}$. Symbols: experimental data from ${ }^{62}$; lines: prediction with present model.

Figure 7 shows the comparison between model predictions and experimental data of Mueller et al. ${ }^{61}$ for $\mathrm{H}_{2} / \mathrm{O}_{2}$ oxidation in the presence of $532 \mathrm{ppm} \mathrm{NO}$ in a flow reactor at 10 atm and $802 \mathrm{~K}$. We observe $\mathrm{NO}$ to $\mathrm{NO}_{2}$ conversion which mainly occurs via the same reaction $\left(\mathrm{NO}+\mathrm{HO}_{2} \leftrightharpoons \mathrm{NO}_{2}+\mathrm{OH}\right)$ as in the JSR shown in Figure 5. 


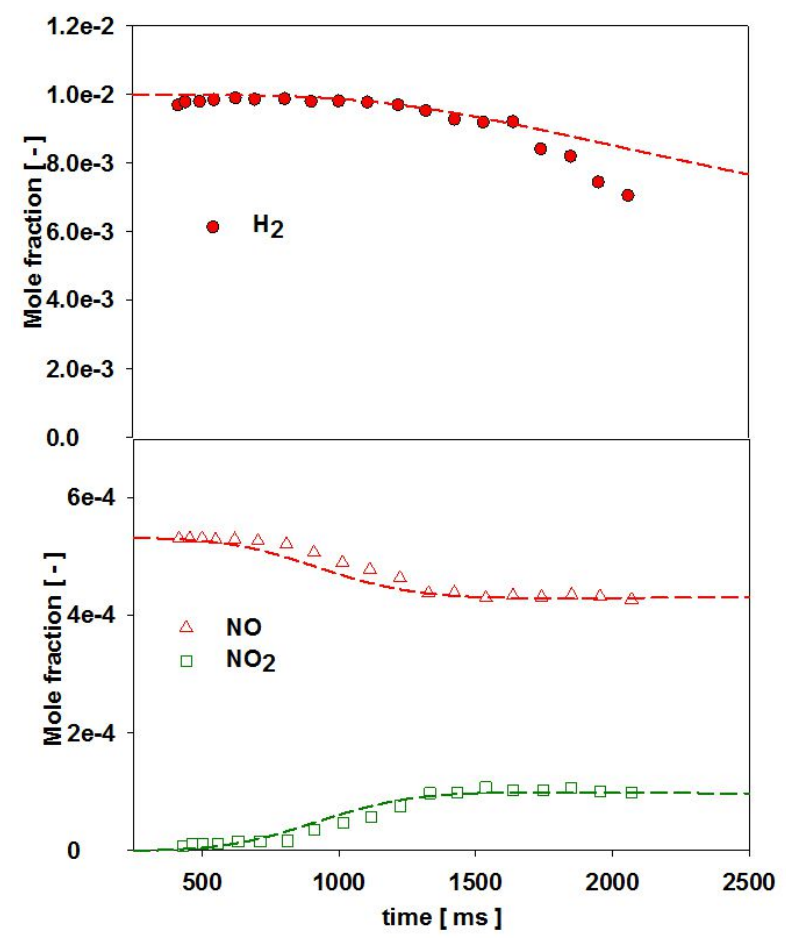

Figure 7: Speciation of $\mathrm{H}_{2}(1 \%) / \mathrm{O}_{2}(2 \%) / \mathrm{NO}(532 \mathrm{ppm}) / \mathrm{N}_{2}$ oxidation in flow reactor at $10 \mathrm{~atm}$ and 802 K. Symbols: experimental data from Mueller et al. ${ }^{61}$; lines: prediction with present model. Simulation lines are shifted by $200 \mathrm{~ms}$ to match fuel consumption.

Figure 8 shows the results for the mutual oxidation of $\mathrm{CO}$ and NO in a flow reactor studied by Glarborg et al. ${ }^{64}$. The upper figure shows the oxidation of $\mathrm{CO}$ to $\mathrm{CO}_{2}$ which proceeds mainly via $\mathrm{CO}+\mathrm{OH} \rightleftharpoons \mathrm{CO}_{2}+\mathrm{H}$ while the lower figure shows the conversion of $\mathrm{NO}$ to $\mathrm{NO}_{2}$. The oxidation of $\mathrm{NO}$ to $\mathrm{NO}_{2}$ proceeds primarily through the reaction $\mathrm{NO}+\mathrm{HO}_{2} \rightleftharpoons \mathrm{NO}_{2}+\mathrm{OH}$ with minor contributions from the reactions $\mathrm{NO}+\mathrm{O}(+\mathrm{M}) \rightleftharpoons \mathrm{NO}_{2}(+\mathrm{M}), \quad \mathrm{NO}+\mathrm{OH}(+\mathrm{M}) \rightleftharpoons \mathrm{HONO}(+\mathrm{M}) \quad$ and $\mathrm{HONO}+\mathrm{OH} \rightleftharpoons \mathrm{NO}_{2}+\mathrm{H}_{2} \mathrm{O}$. In this moist $\mathrm{CO} / \mathrm{NO}$ oxidation system $\mathrm{HO}_{2}$ is formed entirely by recombination of $\mathrm{H}$ atoms with $\mathrm{O}_{2}$, which is the rate limiting step in the $\mathrm{NO}$ to $\mathrm{NO}_{2}$ conversion. The complex effect of $\mathrm{NO}$ on the $\mathrm{CO}$ oxidation rate can be understood in terms of the competition between $\mathrm{NO}+\mathrm{HO}_{2} \rightleftharpoons \mathrm{NO}_{2}+\mathrm{OH}$ which promotes the oxidation process and the reactions $\mathrm{NO}+\mathrm{O}$ 
$(+\mathrm{M}) \rightleftharpoons \mathrm{NO}_{2}$ and $\mathrm{NO}+\mathrm{OH}(+\mathrm{M}) \rightleftharpoons \mathrm{HONO}(+\mathrm{M})$ which leads to recombination of the main chain carriers. The model agrees very well with the experimental results. Both $\mathrm{CO} / \mathrm{CO}_{2}$ and $\mathrm{NO} / \mathrm{NO}_{2}$ conversion are predicted well over the range of conditions investigated (see Figure S16 - Figure S18).

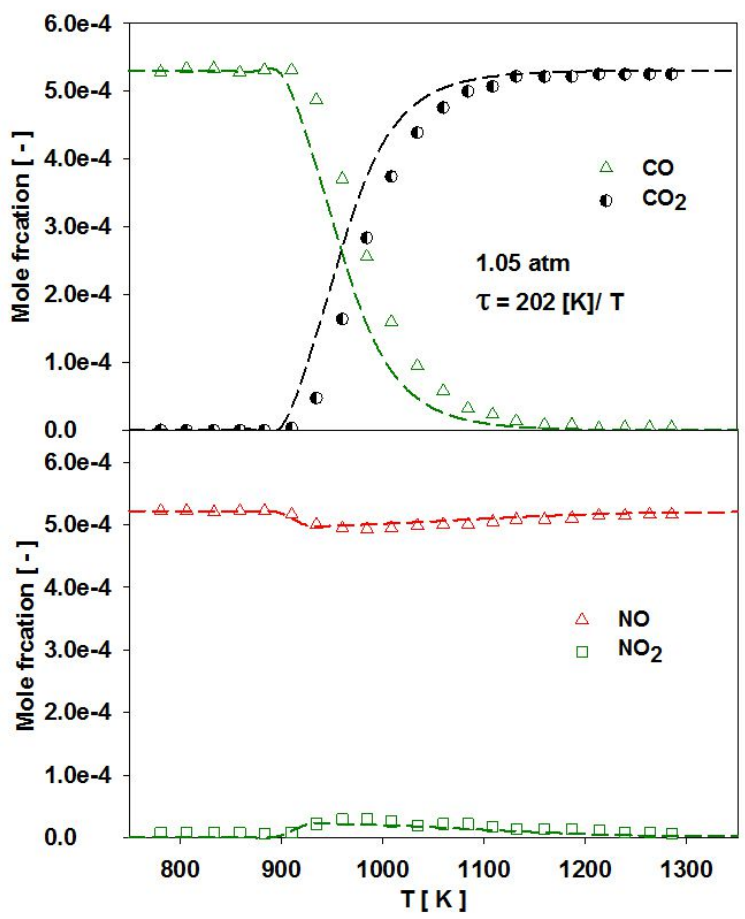

Figure 8: Speciation of $\mathrm{CO}(530 \mathrm{ppm}) / \mathrm{NO}(522 \mathrm{ppm}) / \mathrm{O}_{2}(4.2 \%) / \mathrm{H}_{2} \mathrm{O}(5.2 \%) / \mathrm{N}_{2}$ oxidation in flow reactor at $1.05 \mathrm{~atm}$, residence time, $\tau=202[\mathrm{~K}] / \mathrm{T}$. Symbols: experimental data from Glarborg et al. ${ }^{64}$; lines: prediction with present model.

Speciation in a burner stabilized flame: Speciation predictions for premixed burner stabilized flames receive less attention in the literature than speciation predictions in reactors. However, burner stabilized flames provide important information about species formation and consumption in the reaction zone and subsequently about emission formation pathways. They are the major experimental setup used to study the formation of polycyclic aromatic hydrocarbons (PAHs) and 
$\mathrm{NO}_{\mathrm{x}}$ from carbon based fuels. For all premixed flames the diffusion of small radicals is the determining process for the flame structure. The concentration of the radical pool species $\mathrm{O}, \mathrm{H}$ and $\mathrm{OH}$ during the oxidation of the fuels are the most important species controlling the reactivity of the system. Therefore we give in this study special attention to the speciation predictions for burner stabilized flames.

Figure 9 shows the measured species profiles in a low pressure, fuel rich $(\phi=1.91) \mathrm{H}_{2} / \mathrm{O}_{2} / \mathrm{NH}_{3} / \mathrm{Ar}$ premixed flame studied by Vandooren ${ }^{95}$ in comparison to model predictions. Calculations were performed, using the temperature profile from ${ }^{95}$ (dash lines), and by solving the energy conservation equation (lines). It can be seen that the overall model prediction is in good agreement with the measurements. The proposed kinetic scheme well predicts the intermediates species and the radical pool in the flame. The calculated temperature profile results in a better agreement of the predicted species concentrations. This is also seen for close to equilibrium conditions at larger heights above the burner. As the equilibrium conditions are independent on the kinetic mechanism this indicates that the calculated temperature is accurate. Further simulations of burner stabilized flames are available in the supporting information (Figure S19-Figure S25). 


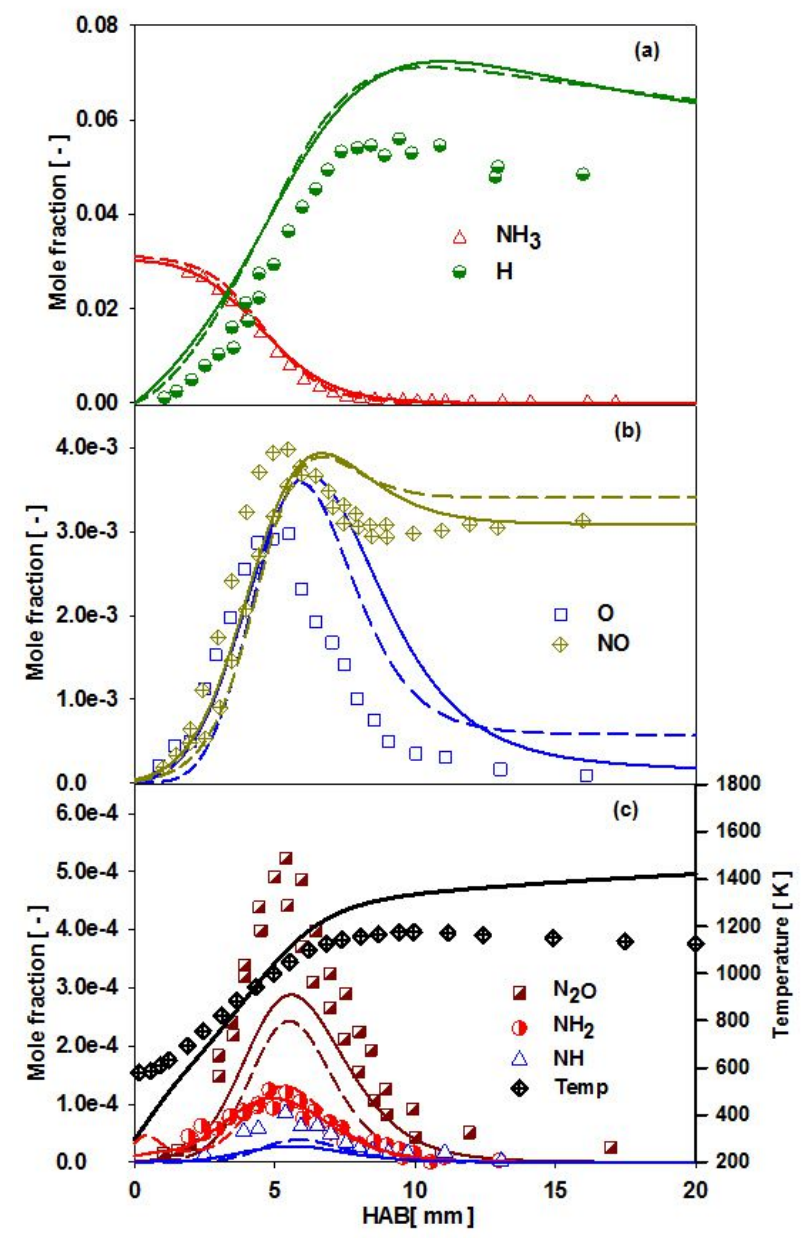

Figure 9: Speciation comparison between experimental data and model predictions for a fuel rich $\mathrm{H}_{2} / \mathrm{O}_{2} / \mathrm{NH}_{3} / \mathrm{Ar}(\phi=1.91)$ premixed burner stabilized flame at $4.7 \mathrm{kPa}$. Symbols: experimental data from ${ }^{95}$. Dashed lines: model predictions imposing the experimental temperature profile, solid line: model predicted temperature profile.

Figure 10 compares the experimental species profiles of a low pressure $(6.66 \mathrm{kPa})$, stoichiometric $(\phi=1.0) \mathrm{CO} / \mathrm{N}_{2} \mathrm{O}$ flame studied by Dindi et al. ${ }^{74}$ against the model predictions from this work. The simulations were performed imposing the experimental temperature profile as provided by ${ }^{74}$ in their study. As we can see in Figure 10 the species consumption and formation profile is well predicted by the model. It can be noted that the model is also capable to address the kinetics 
between $\mathrm{NO}_{\mathrm{x}}$ and $\mathrm{CO}$ species. Further comparison between experimental data and model predictions for fuel rich conditions of the $\mathrm{CO} / \mathrm{N}_{2} \mathrm{O}$ flame can be seen in Figure $\mathrm{S} 24$ and Figure S25.

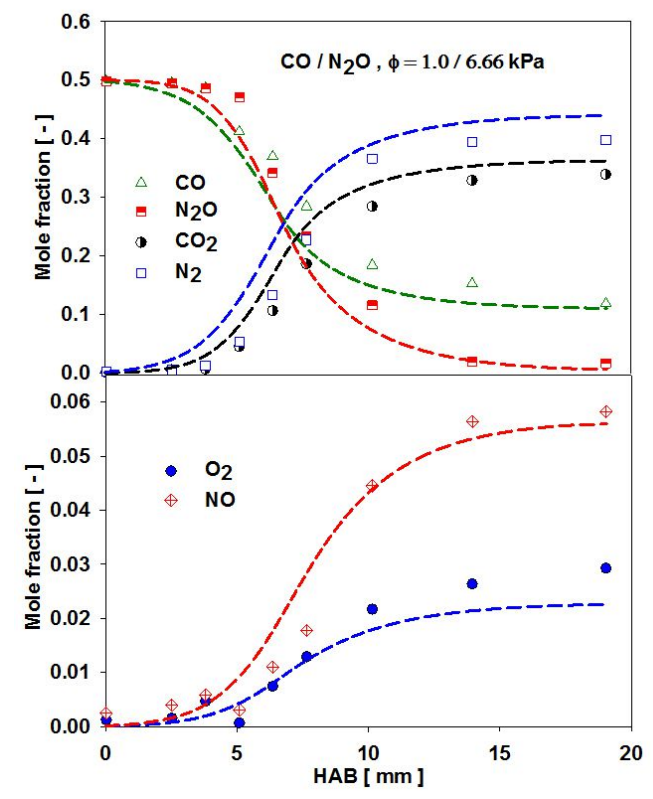

Figure 10: Speciation comparison between experimental data and model predictions for a $\phi=1.0$ premixed burner stabilized $\mathrm{CO}(0.5) / \mathrm{N}_{2} \mathrm{O}(0.5)$ flame at $6.66 \mathrm{kPa}$. Symbols: experimental data from ${ }^{74}$. Dashed lines: model predictions imposing the experimental temperature profile.

\section{$\underline{\text { Reaction path analysis in a burner stabilized flame }}$}

Figure 11 shows the reaction pathway analysis based on the nitrogen atom for the laminar premixed burner stabilized flames in Figures 9 and 10 . In analyzing the $\mathrm{H}_{2}(35.4 \%) / \mathrm{O}_{2} / \mathrm{NH}_{3}(2.9 \%) /$ Ar rich flame studied by the Vandooren ${ }^{95}$ (see Figure 9) with imposing the experimental temperature profile we observe that almost all of the $\mathrm{NH}_{3}$ is decomposed to form the amidogen $\left(\mathrm{NH}_{2}\right)$ radical reacting with $\mathrm{H}, \mathrm{OH}$ and $\mathrm{O}$ radicals. Among these three radicals, the 
$\mathrm{H}$ atom reacting with $\mathrm{NH}_{3}$ is the main reaction forming $\mathrm{NH}_{2}$ while least is contributed by $\mathrm{O}$ atoms. Furthermore, the $\mathrm{NH}_{2}$ radical reacts with $\mathrm{H}$ to form the imidogen $(\mathrm{NH})$ radical. The $\mathrm{NH}$ radical consumes almost $67 \%$ of $\mathrm{NH}_{2}$ and almost $27 \%$ of $\mathrm{NH}_{2}$ is consumed via the reaction $\mathrm{NH}_{2}+\mathrm{O} \rightleftharpoons \mathrm{HNO}+\mathrm{H}$ forming the nitroxyl (HNO) radical. Imidogen radicals are further decomposed forming $\mathrm{N}$ atoms via the reaction $\mathrm{NH}+\mathrm{H} \rightleftharpoons \mathrm{N}+\mathrm{H}_{2}$ and $25 \%$ of these $\mathrm{N}$ radicals react with $\mathrm{OH}$ and $\mathrm{O}_{2}$ to form $\mathrm{NO}$ while the remaining $75 \%$ of $\mathrm{N}$ atoms contribute for the formation of $\mathrm{N}_{2}$ by reacting with NO. The HNO radical, which was initially produced, directly contributes to NO formation by reacting with $\mathrm{H}$ atoms via the reaction $\mathrm{HNO}+\mathrm{H} \rightleftharpoons \mathrm{NO}+\mathrm{H}_{2}$.

(a)

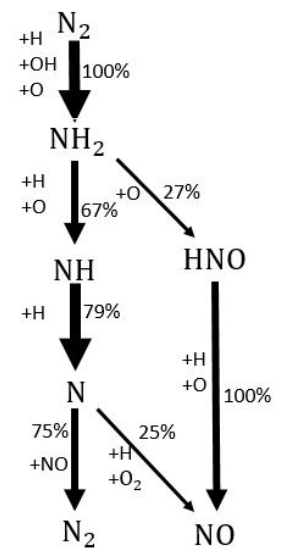

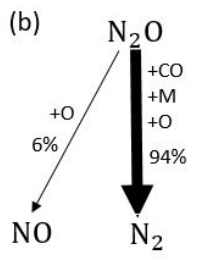

Figure 11: Flow analysis (a) $\mathrm{NH}_{3}$ decomposition and the $\mathrm{NO}$ formation pathway in the fuel rich flame ( $\phi=1.91$ ) shown in Figure 9; (b) $\mathrm{N}_{2} \mathrm{O}$ consumption and $\mathrm{NO}$ formation in the $\mathrm{CO} / \mathrm{N}_{2} \mathrm{O}$ flame shown in Figure 10. The numbers in the flow diagram indicate the percentage flow based on the $\mathrm{N}$ atom.

For the stoichiometric $\mathrm{CO} / \mathrm{N}_{2} \mathrm{O}$ flame as shown in Figure 10 the most important reactions are $\mathrm{CO}+\mathrm{N}_{2} \mathrm{O} \leftrightharpoons \mathrm{CO}_{2}+\mathrm{N}_{2}, \mathrm{~N}_{2} \mathrm{O}(+\mathrm{M}) \leftrightharpoons \mathrm{N}_{2}+\mathrm{O}, \mathrm{N}_{2} \mathrm{O}+\mathrm{O} \leftrightharpoons \mathrm{N}_{2}+\mathrm{O}_{2}$ and $\mathrm{N}_{2} \mathrm{O}+\mathrm{O} \leftrightharpoons \mathrm{NO}+\mathrm{NO}$. Almost all the $\mathrm{CO}$ is consumed via the reaction $\mathrm{CO}+\mathrm{N}_{2} \mathrm{O} \leftrightharpoons \mathrm{CO}_{2}+\mathrm{N}_{2}$. Most of the $\mathrm{N}_{2} \mathrm{O}(94 \%)$ is consumed to form 
$\mathrm{N}_{2}$ via the first three reactions among which the first reaction $\left(\mathrm{CO}+\mathrm{N}_{2} \mathrm{O} \leftrightharpoons \mathrm{CO}_{2}+\mathrm{N}_{2}\right)$ contributes most while $\mathrm{N}_{2} \mathrm{O}+\mathrm{O} \leftrightharpoons \mathrm{NO}+\mathrm{NO}$ contributes least. The last two reactions $\left(\mathrm{N}_{2} \mathrm{O}+\mathrm{O} \leftrightharpoons \mathrm{N}_{2}+\mathrm{O}_{2}\right.$ and $\mathrm{N}_{2} \mathrm{O}+\mathrm{O} \leftrightharpoons \mathrm{NO}+\mathrm{NO}$ ) control the formation of $\mathrm{O}_{2}$ and $\mathrm{NO}$.

\section{$\underline{3.2}$ Brief discussion of $\mathrm{C}_{1} / \mathrm{NO}_{\mathrm{x}}$ model}

Figure 12 follows up the discussion in our recent publication Goos et al. ${ }^{24}$. The figure shows that the current model agrees with the accurate predictions of our former publication ${ }^{24}$. Changes in the base chemistry, and the addition of species in the $\mathrm{H} / \mathrm{N} / \mathrm{O}$ system do not change former conclusions. The thermodata for NCN are highly sensitive on the predicted NO emissions, and we recommend the use of $\Delta_{\mathrm{f}} \mathrm{H}_{298}^{0}=457.7 \mathrm{~kJ} / \mathrm{mol}^{24}$ for $\mathrm{NCN}$.

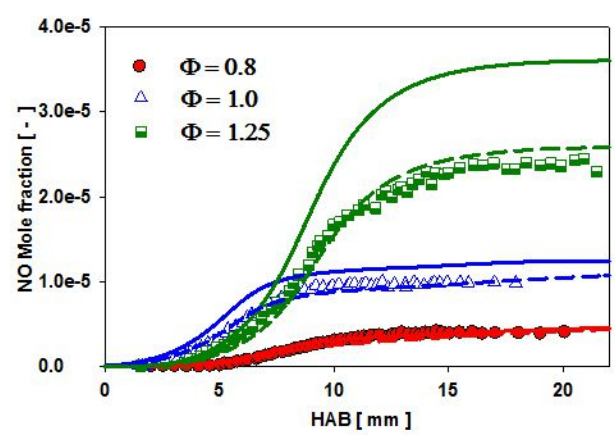

Figure 12: Comparison between experimental $\mathrm{NO}$ profiles and model predictions in a $\mathrm{CH}_{4} / \mathrm{O}_{2} / \mathrm{N}_{2}$ premixed flame at $5.3 \mathrm{kPa}$ and different equivalence ratios. Symbols: experiments from Lamoureux et al. ${ }^{16}$; dashed lines: this model with $\mathrm{NCN}$ heat of formation, $\Delta_{\mathrm{f}} \mathrm{H}_{298}^{0}=457.7 \mathrm{~kJ} / \mathrm{mol}$ from Goos et al. ${ }^{24}$; solid lines: this model with $\mathrm{NCN}$ heat of formation $\Delta_{\mathrm{f}} \mathrm{H}_{298}^{0}=444.1 \mathrm{~kJ} / \mathrm{mol}$ suggested by Lamoureux et al. ${ }^{16}$. 


\section{Effect of Nitrogenated Species Thermochemistry on model predictions}

Very recently, Glarborg et al. ${ }^{101}$ investigated the nitrogen chemistry and reevaluated the thermodynamics properties of nitrogenated species and some hydrocarbon radicals using the Active Thermochemical Tables (ATcT) approach ${ }^{102,103}$. Klippenstein et al. ${ }^{104}$ studied the prompt NO formation in burner stabilized methane premixed flame and used thermodata of Glarborg et al. ${ }^{101}$. To study the effect of nitrogenated species thermochemistry on our model we replaced the complete nitrogenated species thermochemistry with the data from Glarborg et al. ${ }^{101}$ and performed simulations for some of the key experiments used for the model development.
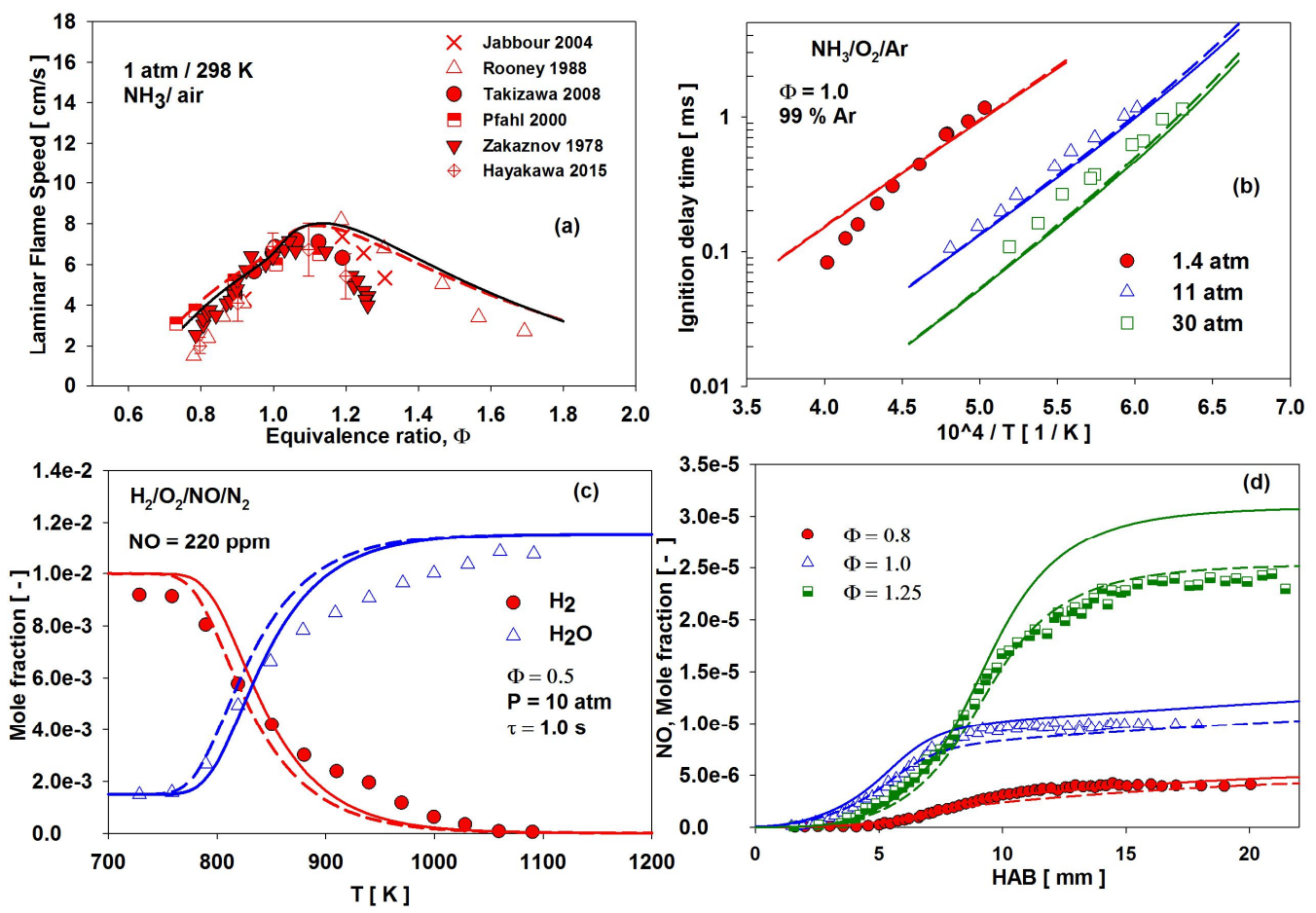

Figure 13: Laminar flame speed of $\mathrm{NH}_{3} /$ air blends at 1 atm and $298 \mathrm{~K}$, (a) (experiments same as in figure 1); Ignition delay time of $\mathrm{NH}_{3} / \mathrm{O}_{2} / \mathrm{Ar}$ at $\phi=1.0$ in shock tube, (b) (experiments same as in figure 2); Speciation in jet stirred reactor for $\mathrm{H}_{2} / \mathrm{O}_{2} / \mathrm{NO} / \mathrm{N}_{2}$, (c) (experiments same as in figure 
5); Speciation in $\mathrm{CH}_{4} / \mathrm{O}_{2} / \mathrm{N}_{2}$ premixed burner stabilized flame, (d) (experiments same as in figure 12). Dashed lines: predictions of this model, solid lines: model prediction using the nitrogenated species thermochemistry from Glarborg et al. ${ }^{101}$.

Only a small difference in predicted laminar flame speeds at $1 \mathrm{~atm}$ and $298 \mathrm{~K}$ (Figure 13(a)) on the lean side was observed. The impact on predicted ignition delay times is negligible (Figure 13 (b)). In Figure 13 (c) using the thermochemistry suggested by Glaborg et al. decreases the reactivity at low temperatures and increases the onset temperature of $\mathrm{H}_{2}$ consumption by $10 \mathrm{~K}$. We found that this shift in reactivity is particularly due to the $1.9 \mathrm{~kJ} / \mathrm{mol}$ lower heat of formation at $298 \mathrm{~K}$ of the $\mathrm{HONO}$ molecule.

The only significant impact we notice using the complete nitrogenated species thermochemistry from Glarborg et al. ${ }^{101}$ is for prompt $\mathrm{NO}$ prediction in a rich, low-pressure $\mathrm{CH}_{4} / \mathrm{O}_{2} / \mathrm{N}_{2}$ premixed burner stabilized flame (Figure 13 (d)). This impact on NO prediction was expected due the different NCN thermochemistry with $\Delta_{\mathrm{f}} \mathrm{H}_{298}^{0}=450.80 \mathrm{~kJ} / \mathrm{mol}$ used by Glarborg et al. ${ }^{101}$ compared to one adopted in our model $\left(\Delta_{\mathrm{f}} \mathrm{H}_{298}^{0}=457.7 \mathrm{~kJ} / \mathrm{mol}\right)$. The sensitivity of NCN

thermochemistry on prompt NO prediction has been discussed by many authors ${ }^{16,24,100,105-107}$ and is also disscused by Glarborg et al. ${ }^{101}$.

\section{Conclusions}

Ammonia has gained growing attention as an alternative fuel or fuel compound, which can be produced from alternative energy sources. As the fuel is carbon free it has zero- $\mathrm{CO}_{2}$ emissions and 
is therefore an alternative to hydrogen as fuel. The advantage of $\mathrm{NH}_{3}$ is its long term storage capability.

In this paper we present a reaction mechanism for the oxidation of ammonia, considering reaction pathways to NO formation and NO reduction. We selected a number of experiments from the literature that demonstrate important features of the $\mathrm{NH}_{3} / \mathrm{NO} / \mathrm{H}_{2} / \mathrm{CO}$ chemistry. It is possible to cover all these features with the here derived, broadly validated reaction mechanism. Special emphasize is made on gas conditions, which allow the $\mathrm{NO}_{\mathrm{x}}$ kinetics to either accelerate or decelerate the oxidation of $\mathrm{H}_{2}$. It is finally demonstrated that the mechanism can be combined with hydrocarbon kinetics to predict NO formation in hydrocarbon flames.

\section{Supporting Information}

Kinetic mechanism, thermochemistry and transport properties of the species used in the mechanism, brief description and convergence criteria of the numerical model used for simulation, additional mechanism validation plots for mixtures listed in Table 2 and rate constant comparison plots for $\mathrm{H}_{2} / \mathrm{CO}$ mechanism.

\section{References}

(1) Westbrook, C. K.; Dryer, F. L. Chemical Kinetic Modeling of Hydrocarbon Combustion. Prog. Energy Combust. Sci. 1984, 10, 1-57.

(2) Salimian, S.; Hanson, R. K.; Kruger, C. H. Ammonia Oxidation in Shock-Heated NH3N2O-Ar Mixtures. Combust. Flame 1984, 56 (1), 83-95. 
(3) Miller, J. a.; Glarborg, P. Modeling the Thermal De-NOx Process: Closing in on a Final

Solution. Int.J.Chem.Kin. 1999, 31 (11), 757-765.

(4) Miller, J. A.; Pilling, M. J.; Troe, J. Unravelling Combustion Mechanisms through a

Quantitative Understanding of Elementary Reactions. Proc. Combust. Inst. 2005, 30

(1), 43-88.

(5) Schmidt, C. C.; Bowman, C. T. Flow Reactor Study of the Effect of Pressure on the

Thermal De-NOx Process. Combust. Flame 2001, 127 (1-2), 1958-1970.

(6) Lan, R.; Irvine, J. T. S.; Tao, S. Ammonia and Related Chemicals as Potential Indirect

Hydrogen Storage Materials. Int. J. Hydrogen Energy 2012, 37 (2), 1482-1494.

(7) Wang, W.; Herreros, J. M.; Tsolakis, A.; York, A. P. E. Ammonia as Hydrogen Carrier for

Transportation; Investigation of the Ammonia Exhaust Gas Fuel Reforming. Int. J.

Hydrogen Energy 2013, 38 (23), 9907-9917.

(8) Zamfirescu, C.; Dincer, I. Ammonia as a Green Fuel and Hydrogen Source for

Vehicular Applications. Fuel Process. Technol. 2009, 90 (5), 729-737.

(9) Mørch, C. S.; Bjerre, A.; Gøttrup, M. P.; Sorenson, S. C.; Schramm, J.

Ammonia/Hydrogen Mixtures in an SI-Engine: Engine Performance and Analysis of a 
Proposed Fuel System. Fue/2011, 90 (2), 854-864.

(10) Reiter, A. J.; Kong, S. C. Combustion and Emissions Characteristics of CompressionIgnition Engine Using Dual Ammonia-Diesel Fuel. Fue/2011, 90 (1), 87-97.

(11) https://nh3fuelassociation.org/.

(12) Allen, M. T.; Yetter, R. A.; Dryer, F. L. High Pressure Studies of Moist Carbon Monoxide / Nitrous Oxide Kinetics. Combust. Flame 1997, 109 (3), 449-470.

(13) Lindstedt, R. P.; Lockwood, F. C.; Selim, M. A. Detailed Kinetic Modelling of Chemistry and Temperature Effects on Ammonia Oxidation. Combust. Sci. Technol. 1994, 99 (46), 253-276.

(14) Duynslaegher, C.; Contino, F.; Vandooren, J.; Jeanmart, H. Modeling of Ammonia Combustion at Low Pressure. Combust. Flame 2012, 159 (9), 2799-2805.

(15) Tian, Z.; Li, Y.; Zhang, L.; Glarborg, P.; Qi, F. An Experimental and Kinetic Modeling Study of Premixed NH3/CH4/O2/Ar Flames at Low Pressure. Combust. Flame 2009, $156(7), 1413-1426$.

(16) Lamoureux, N.; Merhubi, H. El; Pillier, L.; de Persis, S.; Desgroux, P. Modeling of NO Formation in Low Pressure Premixed Flames. Combust. Flame 2016, 163, 557-575. 
(17) Mathieu, O.; Petersen, E. L. Experimental and Modeling Study on the High-

Temperature Oxidation of Ammonia and Related NOx Chemistry. Combust. Flame

2015, $162(3), 554-570$.

(18) Hayakawa, A.; Goto, T.; Mimoto, R.; Arakawa, Y.; Kudo, T.; Kobayashi, H. Laminar

Burning Velocity and Markstein Length of Ammonia/Air Premixed Flames at Various

Pressures. Fue/2015, 159, 98-106.

(19) Xiao, H.; Valera-Medina, A. Chemical Kinetic Mechanism Study on Premixed

Combustion of Ammonia/Hydrogen Fuels for Gas Turbine Use. J. Eng. Gas Turbines

Power 2017, 139 (8), 081504.

(20) Li, J.; Huang, H.; Kobayashi, N.; He, Z.; Nagai, Y. Study on Using Hydrogen and Ammonia as Fuels: Combustion Characteristics and NOx Formation. Int. J. ENERGY

Res. 2014, 38, 1214-1223.

(21) Zhang, Y.; Mathieu, O.; Petersen, E. L.; Bourque, G.; Curran, H. J. Assessing the Predictions of a NOx Kinetic Mechanism on Recent Hydrogen and Syngas Experimental Data. Combust. Flame 2017, 182, 122-141.

(22) Hoyermann, K.; Mauss, F.; Zeuch, T. A Detailed Chemical Reaction Mechanism for the Oxidation of Hydrocarbons and Its Application to the Analysis of Benzene 
Formation in Fuel-Rich Premixed Laminar Acetylene and Propene Flames. Phys.

Chem. Chem. Phys. 2004, 6 (14), 3824-3835.

(23) Ahmed, S. S.; Mau; Moreac, G.; Zeuch, T. A Comprehensive and Compact N-Heptane Oxidation Model Derived Using Chemical Lumping. Phys. Chem. Chem. Phys. 2007, 9 (9), 1107-1126.

(24) Goos, E.; Sickfeld, C.; Mauss, F.; Seidel, L.; Ruscic, B.; Burcat, A.; Zeuch, T. Prompt NO Formation in Flames: The Influence of NCN Thermochemistry. Proc. Combust. Inst. 2013, 34 (1), 657-666.

(25) Seidel, L.; Moshammer, K.; Wang, X.; Zeuch, T.; Kohse-Höinghaus, K.; Mauss, F. Comprehensive Kinetic Modeling and Experimental Study of a Fuel-Rich, Premixed $n$ Heptane Flame. Combust. Flame 2015, 162 (5), 2045-2058.

(26) Hoyermann, K.; Mauß, F.; Olzmann, M.; Welz, O.; Zeuch, T. Exploring the Chemical Kinetics of Partially Oxidized Intermediates by Combining Experiments, Theory, and Kinetic Modeling. Phys. Chem. Chem. Phys. 2017, 19 (28), 18128-18146.

(27) Moshammer, K.; Seidel, L.; Wang, Y.; Selim, H.; Sarathy, S. M.; Mauss, F.; Hansen, N. Aromatic Ring Formation in Opposed-Flow Diffusive 1,3-Butadiene Flames. Proc. Combust. Inst. 2015, 000, 1-9. 
(28) Westbrook, C.; Mehl, M.; Pitz, W. J.; Kukkadapu, G.; Wagnon, S. W.; Zhang, K. Multi-

Fuel Surrogate Chemical Kinetic Mechanisms for Real World Applications. Phys.

Chem. Chem. Phys. 2018, 20, 10588-10600.

(29) Baulch, D. L.; Bowman, C. T.; Cobos, C. J.; Cox, R. A.; Just, T.; Kerr, J. A.; Pilling, M. J.;

Stocker, D.; Troe, J.; Walker, R. W.; et al. Evaluated Kinetic Data for Combustion

Modeling : Supplement II Evaluated Kinetic Data for Combustion Modeling :

Supplement II. J. Phys. Chem. Ref. Data 34 2005, 34, 757-1397.

(30) Hong, Z.; Cook, R. D.; Davidson, D. F.; Hanson, R. K.; January, R. V; Re, V.; Recei, M.;

April, V. A Shock Tube Study of $\mathrm{OH}+\mathrm{H} 2 \mathrm{O} 2=\mathrm{H} 2 \mathrm{O}+\mathrm{HO} 2$ and $\mathrm{H} 2 \mathrm{O} 2+\mathrm{M}=2 \mathrm{OH}+\mathrm{M}$

Using Laser Absorption of H $2 \mathrm{O}$ and OH. J. Phys. Chem. A 2010, 114, 5718-5727.

(31) Hong, Z.; Lam, K.; Sur, R.; Wang, S.; Davidson, D. F.; Hanson, R. K. On the Rate

Constants of $\mathrm{OH}+\mathrm{HO} 2$ and $\mathrm{HO} 2+\mathrm{HO} 2$ : A Comprehensive Study of $\mathrm{H} 2 \mathrm{O} 2$ Thermal

Decomposition Using Multi-Species Laser Absorption. Proc. Combust. Inst. 2013, 34

(1), 565-571.

(32) Troe, J. The Thermal Dissociation/Recombination Reaction of Hydrogen Peroxide $\mathrm{H} 2 \mathrm{O} 2(+\mathrm{M})=2 \mathrm{OH}(+\mathrm{M})$ III.. Analysis and Representation of the Temperature and Pressure Dependence over Wide Ranges. Combust. Flame 2011, 158 (4), 594-601. 
(33) Varga, T.; Olm, C.; Nagy, T.; Zsély, I. G.; Valkó, É.; Pálvölgyi, R.; Curran, H. J.; Turányi, T. Development of a Joint Hydrogen and Syngas Combustion Mechanism Based on an Optimization Approach. Int. J. Chem. Kinet. 2016, 48 (8), 407-422.

(34) Li, J.; Zhao, Z.; Kazakov, A.; Dryer, F. L. An Updated Comprehensive Kinetic Model of Hydrogen Combustion. Int. J. Chem. Kinet. 2004, 36, 566-575.

(35) Sun, H.; Yang, S. I.; Jomaas, G.; Law, C. K. High-Pressure Laminar Flame Speeds and Kinetic Modeling of Carbon Monoxide/Hydrogen Combustion. Proc. Combust. Inst. 2007, 31 /, 439-446.

(36) Conaire, M. O.; Curran, H. J.; Simmie, J. M.; Pitz, W. J.; Westbrook, C. K. A Comprehensive Modeling Study of Hydrogen Oxidation. Int. J. Chem. Kinet. 2004, 36, $603-622$.

(37) Hong, Z.; Davidson, D. F.; Hanson, R. K. An Improved H2 / O2 Mechanism Based on Recent Shock Tube / Laser Absorption Measurements. Combust. Flame 2011, 158 (4), 633-644.

(38) Burke, M. P.; Chaos, M.; Ju, Y.; Dryer, F. L.; Klippenstein, S. J. Comprehensive H2/O2 Kinetic Model for High-Pressure Combustion. Int. J. Chem. Kinet. 2012, 44, 444-474. 
(39) Kéromnès, A.; Metcalfe, W. K.; Heufer, K. A.; Donohoe, N.; Das, A. K.; Sung, C. J.;

Herzler, J.; Naumann, C.; Griebel, P.; Mathieu, O.; et al. An Experimental and Detailed Chemical Kinetic Modeling Study of Hydrogen and Syngas Mixture Oxidation at Elevated Pressures. Combust. Flame 2013, 160 (6), 995-1011.

(40) Konnov, A. A. Remaining Uncertainties in the Kinetic Mechanism of Hydrogen Combustion. Combust. Flame 2008, 152, 507-528.

(41) Alekseev, V. A.; Christensen, M.; Konnov, A. A. The Effect of Temperature on the Adiabatic Burning Velocities of Diluted Hydrogen Flames: A Kinetic Study Using an Updated Mechanism. Combust. Flame 2015, 162 (5), 1884-1898.

(42)

Davis, S. G.; Joshi, A. V; Wang, H.; Egolfopoulos, F. An Optimized Kinetic Model of H2 / CO Combustion. Proc. Combust. Inst. 2005, 30, 1283-1292.

(43) Saxena, P.; Williams, F. A. Testing a Small Detailed Chemical-Kinetic Mechanism for the Combustion of Hydrogen and Carbon Monoxide. Combust. Flame 2006, 145, 316323.

(44) http://www.tdtvt.de/Download/download.php.

(45) Allen, M. T.; Yetter, R. A.; Dryer, F. L. Hydrogen / Nitrous Oxide Kinetics-Implications 
of the NxHy Species. Combust. Flame 1998, 112, 302-311.

(46) Griffiths, J. F.; Barnard, A. Flame and Combustion, Third edit.; Black Academic and professional, 1995; Vol. 3.

(47) Coppens, F. H. V.; De Ruyck, J.; Konnov, A. A. The Effects of Composition on Burning Velocity and Nitric Oxide Formation in Laminar Premixed Flames of $\mathrm{CH} 4+\mathrm{H} 2+\mathrm{O} 2+$ N2. Combust. Flame 2007, 149 (4), 409-417.

(48) Klaus, P. Entwicklung Eines Detaillierten Reaktionsmechanismus Zur Modellierung Der Bildung von Stickoxiden in Flammenfronten, PhD thesis, Ruprecht-KarlsUniversität Heidelberg, Heidelberg, Germany, 1997.

(49) Klippenstein, S. J.; Harding, L. B.; Glarborg, P.; Miller, J. A. The Role of NNH in NO Formation and Control. Combust. Flame 2011, 158 (4), 774-789.

(50) Park, J.; Lin, M. C. A Mass Spectrometric Study of the NH2 + NO2 Reaction. J. Phys. Chem. A 1997, 101 (14), 2643-2647.

(51) Skreiberg, Ø.; Kilpinen, P.; Glarborg, P. Ammonia Chemistry below $1400 \mathrm{~K}$ under FuelRich Conditions in a Flow Reactor. Combust. Flame 2004, 136 (4), 501-518.

(52) Klippenstein, S. J.; Harding, L. B.; Ruscic, B.; Sivaramakrishnan, R.; Srinivasan, N. K.; 
Su, M.; Michael, J. V. Thermal Decomposition of NH $2 \mathrm{OH}$ and Subsequent Reactions :

Ab Initio Transition State Theory and Reflected Shock Tube Experiments. J. Phys.

Chem. A 2009, 113 (8), 10241-10259.

(53) Rasmussen, C. L.; Hansen, Jø.; Marshall, P.; Glarborg, P. Experimental Measurements and Kinetic Modeling of $\mathrm{CO} / \mathrm{H} 2 / \mathrm{O} 2 / \mathrm{NOx}$ Conversion at High Pressure. Int. J. Chem.

Kinet. 2008, 40, 454-480.

(54) Rohrig, M.; Petersen, E. L.; Davidson, D. F.; Hanson, R. K. The Pressure Dependence of the Thermal Decomposition of N2O. Int. J. Chem. Kinet. 1996, 28 (8), 599-608.

(55) Powell, O. A.; Papas, P.; Dreyer, C. B. Hydrogen- and C1-C3 Hydrocarbon-Nitrous Oxide Kinetics in Freely Propagating and Burner-Stabilized Flames, Shock Tubes, and Flow Reactors. Combust. Sci. Technol. 2010, 182 (3), 252-283.

(56) Hidaka, Y.; Takuma, H.; Suga, M. Shock-Lube Study of the Rate Constant for Excited OH"(,X+) Formation in the N2O-H2 Reaction. J. Phys. Chem. 1985, 89 (23).

(57) Zeldovich, J. The Oxidation of Nitrogen in Combustion and Explosions. Acta Physicochim. URSS 1946, 21 (4), 218.

(58) Glarborg, P.; Alzueta, M. U.; Dam-Johansen, K.; Miller, J. A. Kinetic Modeling of 
Hydrocarbon/Nitric Oxide Interactions in a Flow Reactor. Combust. Flame 1998, 115 (1-2), 1-27.

(59) Glarborg, P.; Kristensen, P. G.; Dam-Johansen, K.; Alzueta, M. U.; Millera, A.; Bilbao, R. Nitric Oxide Reduction by Non-Hydrocarbon Fuels. Implications for Reburning with Gasification Gases. Energy and Fuels 2000, 14 (4), 828-838.

(60) Mendiara, T.; Glarborg, P. Ammonia Chemistry in Oxy-Fuel Combustion of Methane. Combust. Flame 2009, 156 (10), 1937-1949.

(61) Mueller, M. A.; Yetter, R. A.; Dryer, F. L. Flow Reactor Studies and Kinetic Modeling of the $\mathrm{H} 2$ /O2 /NOX and CO/H2O/O2 /NOX Reactions. Int. J. Chem. Kinet. 1999, 31 (2), 705-724.

(62) Dayma, G.; Dagaut, P. Effects of Air Contamination on the Combustion of HydrogenEffect of NO and NO2 Addition on Hydrogen Ignition and Oxidation Kinetics. Combust. Sci. Technol. 2006, 178 (10-11), 1999-2024.

(63) Mathieu, O.; Levacque, A.; Petersen, E. L. Effects of NO2 Addition on Hydrogen Ignition behind Reflected Shock Waves. Proc. Combust. Inst. 2013, 34 (1), 633-640.

(64) Glarborg, P.; Kubel, D.; Kristensen, P. G.; Hansen, J.; Dam-Johansen, K. Interactions 
of CO, NOx and H2O Under Post-Flame Conditions. Combust. Sci. Technol. 1995,

$110-111(1), 461-485$.

(65) Bemand, P. P.; Clyne, M. A. A.; Watson, R. T. Atomic Resonance Fluorescence and

Mass Spectrometry for Measurements of the Rate Constants for Elementary

Reactions: O3PJ + NO2 -> NO + 02 and $\mathrm{NO}+\mathrm{O} 3$-> NO2 + O2. J. Chem. Soc.,

Faraday Trans. 2 1974, 70 (02), 564-576.

(66) Estupiñán, E. G.; Nicovich, J. M.; Wine, P. H. A Temperature-Dependent Kinetics

Study of the Important Stratospheric Reaction O(3P) + NO2 $\rightarrow$ O2 + NO. J. Phys.

Chem. A 2001, 105 (42), 9697-9703.

(67) Avallone, L. M. Measurements of the Temperature-Dependent Rate Coefficient for the Reaction $\mathrm{O}(3 \mathrm{P})+\mathrm{NO} 2 \rightarrow \mathrm{NO}+$ O2. J. Photochem. Photobiol. A Chem. 2003, 157 (2-3), 231-236.

(68) Shiekh, B. A.; Kaur, D.; Seth, B.; Mahajan, S. The Theoretical-Cum-Statistical Approach for the Investigation of Reaction $\mathrm{NO} 2+\mathrm{O}(3 \mathrm{P}) \rightarrow \mathrm{NO}+\mathrm{O} 2$ using SCTST and a Full Anharmonic VPT2 Model. Chem. Phys. Lett. 2016, 662, 244-249.

(69) Glarborg, P.; Alzueta, M. U.; Kjærgaard, K.; Dam-Johansen, K. Oxidation of Formaldehyde and Its Interaction with Nitric Oxide in a Flow Reactor. Combust. Flame 
2003, $132(4), 629-638$.

(70) Glarborg, P.; Dam-Johansen, K.; Miller, J. A.; Kee, R. J.; Coltrin, M. E. Modeling the Thermal DeNOx Process in Flow Reactors. Surface Effects and Nitrous-Oxide Formation. Int. J. Chem. Kinet. 1994, 26 (4), 421-436.

(71) Kopp, M.; Brower, M.; Mathieu, O.; Petersen, E.; Güthe, F. CO2* Chemiluminescence Study at Low and Elevated Pressures. Appl. Phys. B Lasers Opt. 2012, 107 (3), 529538.

(72) Powell, O. A.; Papas, P.; Dreyer, C. Laminar Burning Velocities for Hydrogen-, Methane-, Acetylene-, and Propane-Nitrous Oxide Flames. Combust. Sci. Technol. 2009, 181 (7), 917-936.

(73) Sausa, R. C.; Singh, G.; Lemire, G. W.; Anderson, W. R. Molecular Beam Mass Spectrometric and Modeling Studies of Neat and NH3 -Doped Low-Pressure H2/N2O/Ar Flames: Formation and Consumption of NO. Twenty-Sixth Symp. Combust. 1996, 1043-1052.

(74) Dindi, H.; Tsai, H. M.; Branch, M. C. Combustion Mechanism of Carbon Monoxidenitrous Oxide Flames. Combust. Flame 1991, 87 (1), 13-20. 
(75) Mebel, A. M.; Lin, M. C.; Morokuma, K.; Melius, C. F. Theoretical Study of Reactions of $\mathrm{N} 2 \mathrm{O}$ with $\mathrm{NO}$ and $\mathrm{OH}$ Radicals. Intern. J. Chem. Kinet. 1996, 28, 693-703.

(76) Mével, R.; Lafosse, F.; Catoire, L.; Chaumeix, N.; Dupré, G.; Paillard, C. E. Induction Delay Times and Detonation Cell Size Prediction of Hydrogen-Nitrous Oxide-Diluent Mixtures. Combust. Sci. Technol. 2008, 180 (10-11), 1858-1875.

(77) Mathieu, O.; Levacque, A.; Petersen, E. L. Effects of N2O Addition on the Ignition of H2-O2 Mixtures: Experimental and Detailed Kinetic Modeling Study. Int. J. Hydrogen Energy 2012, 37 (20), 15393-15405.

(78) Zhang, K.; Li, Y.; Yuan, T.; Cai, J.; Glarborg, P.; Qi, F. An Experimental and Kinetic Modeling Study of Premixed Nitromethane Flames at Low Pressure. Proc. Combust. Inst. 2011, 33 (1), 407-414.

(79) Mével, R.; Javoy, S.; Lafosse, F.; Chaumeix, N.; Dupré, G.; Paillard, C. E. HydrogenNitrous Oxide Delay Times: Shock Tube Experimental Study and Kinetic Modelling. Proc. Combust. Inst. 2009, 32 I, 359-366.

(80) Hasegawa, T.; Sato, M. Study of Ammonia Removal from Coal-Gasified Fuel. Combust. Flame 1998, 114 (1-2), 246-258. 
(81) Glarborg, P.; Dam-Johansen, K.; Miller, J. A. The Reaction of Ammonia with Nitrogen

Dioxide in a Flow Reactor: Implications for the NH2+ NO2reaction. Int. J. Chem. Kinet.

1995, $27(12), 1207-1220$.

(82) Mebel, A. M.; Diau, E. W. G.; Lin, M. C.; Morokuma, K. Theoretical Rate Constants for the $\mathrm{NH} 3+\mathrm{NOx} \rightarrow \mathrm{NH} 2+\mathrm{HNOx}(x=1,2)$ Reactions by Ab Initio MO/VTST

Calculations. J. Phys. Chem. 1996, 100 (18), 7517-7525.

(83) Kasuya, F.; Glarborg, P.; Johnsson, J. ane; Dam-johansen, K. im. The Thermal Denox Process: Influence of Partial Pressures and Temperature. Chem. Eng. Sci. 1995, 50 (9), 1455-1466.

(84) Song, S.; Golden, D. M.; Hanson, R. K.; Bowman, C. T. A Shock Tube Study of the NH2+NO2 Reaction. Proc. Combust. Inst. 2002, 29 (2), 2163-2170.

(85) Goos, E.; Burcat, A.; Ruscic, B. Third Millennium Ideal Gas and Condensed Phase Thermochemical Database for Combustion with Updates from Active Thermochemical Tables; 2005; Vol. ANL-05/20.

(86) http://logesoft.com/loge-software/.

(87) Zakaznov, V. F.; Kursheva, L. A.; Fedina, Z. I. Determination of Normal Flame Velocity 
and Critical Diameter of Flame Extinction in Ammonia-Air Mixture. Combust. Explos.

Shock Waves 1978, 14 (6), 710-713.

(88) Pfahl, U. J.; Ross, M. C.; Shepherd, J. E.; Pasamehmetoglu, K. O.; Unal, C.

Flammability Limits, Ignition Energy, and Flame Speeds in H2-CH4-NH3- N2O-O2-N2

Mixtures. Combust. Flame 2000, 123 (1-2), 140-158.

(89) Ronney, P. D. Effect of Chemistry and Transport Properties on Near-Limit Flames at

Microgravity. Combust. Sci. Technol. 1988, 59 (1-3), 123-141.

(90) T, J.; DF, C. Burning Velocity and Refrigerant Flammability Classification. ASHRAE

Trans. 2004, 110, 522-533.

(91) Takizawa, K.; Takahashi, A.; Tokuhashi, K.; Kondo, S.; Sekiya, A. Burning Velocity Measurements of Nitrogen-Containing Compounds. J. Hazard. Mater. 2008, 155 (1-2), 144-152.

(92) Lee, J. H.; Lee, S. I.; Kwon, O. C. Effects of Ammonia Substitution on Hydrogen/Air Flame Propagation and Emissions. Int. J. Hydrogen Energy 2010, 35 (20), 1133211341.

(93) Checkel, M. D.; Ting, D. S. K.; Bushe, W. K. Flammability Limits and Burning 
Velocities of Ammonia/Nitric Oxide Mixtures. J. Loss Prev. Process Ind. 1995, 8 (4), 215-220.

(94) Dagaut, P.; Lecomte, F.; Mieritz, J.; Glarborg, P. Experimental and Kinetic Modeling Study of the Effect of NO and SO2 on the Oxidation of $\mathrm{CO}-\mathrm{H} 2$ Mixtures. Int. J. Chem.

Kinet. 2003, 35 (11), 564-575.

(95) Vandooren, J. Comparison of the Experimental Structure of an Ammonia Seeded Rich Hydrogen Oxygen Argon Flame With the Calculated Ones Along Several ReactionMechanisms. Combust. Sci. Technol. 1992, 84 (1-6), 335-344.

(96) Bian, J.; Vandooren, J.; Van Tiggelen, P. J. Experimental Study of the Formation of Nitrous and Nitric Oxides in H2-O2-Ar Flames Seeded with NO and/or NH3. Twenty third Symp. Combust. 1990, 379-386.

(97) Vandooren, J.; Bian, J.; Van Tiggelen, P. J. Comparison of Experimental and Calculated Structures of an Ammonianitric Oxide Flame. Importance of the NH2 + NO Reaction.

Combust. Flame 1994, 98 (4), 402-410.

(98) Duynslaegher, C.; Jeanmart, H.; Vandooren, J. Flame Structure Studies of Premixed Ammonia/Hydrogen/Oxygen/Argon Flames: Experimental and Numerical Investigation. Proc. Combust. Inst. 2009, 32 / (1), 1277-1284. 
(99) Nakamura, H.; Hasegawa, S.; Tezuka, T. Kinetic Modeling of Ammonia/Air Weak

Flames in a Micro Flow Reactor with a Controlled Temperature Profile. Combust.

Flame 2017, 185, 16-27.

(100) Bugler, J.; Somers, K. P.; Simmie, J. M.; Güthe, F.; Curran, H. J. Modeling Nitrogen

Species as Pollutants: Thermochemical Influences. J. Phys. Chem. A 2016, 120 (36), 7192-7197.

(101) Glarborg, P.; Miller, J. A.; Ruscic, B.; Klippenstein, S. J. Modeling Nitrogen Chemistry in Combustion. Prog. Energy Combust. Sci. 2018, 67, 31-68.

(102) Ruscic, B.; Pinzon, R. E.; Morton, M. L.; Von Laszevski, G.; Bittner, S. J.; Nijsure, S. G.; Amin, K. A.; Minkoff, M.; Wagner, A. F. Introduction to Active Thermochemical Tables: Several "Key" Enthalpies of Formation Revisited. J. Phys. Chem. A 2004, 108 (45), 9979-9997.

(103) Ruscic, B.; Pinzon, R. E.; Von Laszewski, G.; Kodeboyina, D.; Burcat, A.; Leahy, D.; Montoy, D.; Wagner, A. F. Active Thermochemical Tables: Thermochemistry for the 21st Century. J. Phys. Conf. Ser. 2005, 16 (1), 561-570.

(104) Klippenstein, S. J.; Pfeifle, M.; Jasper, A. W.; Glarborg, P. Theory and Modeling of Relevance to Prompt-NO Formation at High Pressure. Combust. Flame 2018, 1-15. 
(105) Harding, L. B.; Klippenstein, S. J.; Miller, J. A. Kinetics of CH + N2 Revisited with Multireference Methods. J. Phys. Chem. A 2008, $112(3), 522-532$.

(106) Teng, W. S.; Moskaleva, L. V.; Chen, H. L.; Lin, M. C. Ab Initio Chemical Kinetics for H + NCN: Prediction of NCN Heat of Formation and Reaction Product Branching via Doublet and Quartet Surfaces. J. Phys. Chem. A 2013, 117 (28), 5775-5784.

(107) Faßheber, N.; Dammeier, J.; Friedrichs, G. Direct Measurements of the Total Rate Constant of the Reaction NCN $+\mathrm{H}$ and Implications for the Product Branching Ratio and the Enthalpy of Formation of NCN. Phys. Chem. Chem. Phys. 2014, 16 (23), $11647-11657$. 